Florida International University FIU Digital Commons

\title{
"Across the colour wall:" Gullah linguistic and literary representations in Dubose Heyward's Porgy
}

Charlene Eberly

Florida International University

DOI: $10.25148 /$ etd.FI15101261

Follow this and additional works at: https:// digitalcommons.fiu.edu/etd

Part of the African Languages and Societies Commons, and the English Language and Literature Commons

\section{Recommended Citation}

Eberly, Charlene, "'Across the colour wall:" Gullah linguistic and literary representations in Dubose Heyward's Porgy" (2004). FIU Electronic Theses and Dissertations. 3112.

https://digitalcommons.fiu.edu/etd/3112 
FLORIDA INTERNATIONAL UNIVERSITY

Miami, Florida

"ACROSS THE COLOUR WALL:"

GULLAH LINGUISTIC AND LITERARY REPRESENTATIONS

IN DUBOSE HEYWARD'S PORGY

A thesis submitted in partial fulfillment of the

requirements for the degree of

MASTER OF ARTS

in

ENGLISH

by

Charlene Eberly

2004 
To: Dean R. Bruce Dunlap

College of Arts and Sciences

This thesis, written by Charlene Eberly, and entitled "Across the Colour Wall:" Gullah Linguistic and Literary Representations in DuBose Heyward's Porgy, having been approved in respect to style and intellectual content, is referred to you for judgment.

We have read this thesis and recommend that it be approved.

Carmela Mclntire

Tometro Hopkins

Heather Andrade, Major Professor

Date of Defense: July 20, 2004

The thesis of Charlene Eberly is approved.

Dean R. Bruce Dunlap

College of Arts and Sciences

Dean Douglas Wartzok

University Graduate School

Florida International University, 2004 
C Copyright 2004 by Charlene Eberly

All rights reserved. 


\section{DEDICATION}

I dedicate this thesis to God, who makes all things possible. 


\section{ACKNOWLEDGMENTS}

I wish to thank the members of my committee for the generous gifts of their time and talents. Dr. Carmela McIntire served as guru and friend, giving encouragement and support from day one; she was also a willing reader of early chapter drafts. Dr. Tometro Hopkins was gracious in accepting a literature student's crossover into linguistic waters, and in sharing her knowledge of the Gullah language, along with her linguistic expertise.

My major professor, Dr. Heather Andrade was a godsend. She agreed to direct my thesis on faith, and she guided me gently but firmly through what were sometimes deep waters. I am extremely grateful for her immense knowledge of African American literature and literary theory, of course, but even more so for her ability to see my vision for my thesis and help me make it a reality.

The patrons and staff of the South Carolina Historical Society in Charleston, South Carolina deserve special recognition; without them, my research would not have been possible.

I'd also like to thank Professors Feryal Yavas, Kate Capshaw-Smith, Bruce Harvey, and Peggy Endel for their inspiration, motivation, and support, all of which contributed to my ability to successfully complete my studies and my thesis. Last but not least, the day-to-day support and encouragement of my fellow teaching assistants and graduate students, Maezel Brown and the staff of the English Department, and my students, meant a great deal and kept me going during the long, lonely writing process. 


\section{ABSTRACT OF THE THESIS \\ "ACROSS THE COLOUR WALL:" \\ GULLAH LINGUISTIC AND LITERARY REPRESENTATIONS \\ IN DUBOSE HEYWARD'S PORGY}

by

Charlene Eberly

Florida International University, 2004

Miami, Florida

Professor Heather Andrade, Major Professor

The purpose of this research was to examine a classic text - DuBose Heyward's Porgy (1925) - associated with Southern Literature in relation to its connections to the Gullah culture and language. Close critical scrutiny was made of the 1925 text, two early manuscripts, manuscript fragments, revisions, research notes, and other personal papers from Heyward's estate. Access to these papers helped establish his influences and motivations in writing Porgy.

Employing both linguistic and literary analyses, the findings establish the verisimilitude of Heyward's representation of the Gullah language, rhetorical patterns, culture, beliefs, and practices, linking Porgy to a Gullah literary tradition.

Examination of Heyward's life and times reveals why Porgy sits squarely within the early $20^{\text {th }}$ Century literary genre, African American Literary Realism and thematically anticipates the Harlem Renaissance period. Breaking the mold of the "old South" minstrel-style depictions of black life, Heyward portrayed the Gullah people with integrity and respect. 
I. INTRODUCTION.

II. LITERARY REALISM, BLACK VERNACULAR, AND AFRICAN AMERICAN LITERARY THEORY

III. THE GULLAH LANGUAGE IN PORGY - A LINGUISTIC ANALYSIS ................................................... 25

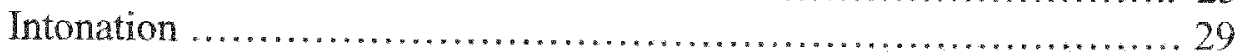

Phonology ....................................................... 30

Lexicon ............................................................. 35

Morphology ........................................................ 37

Syntax .......................................................... 44

IV. GULLAH IDENTITY - THE PEOPLE, CULTURE, AND BELIEFS A LITERARY ANALYSIS ...................................... 47

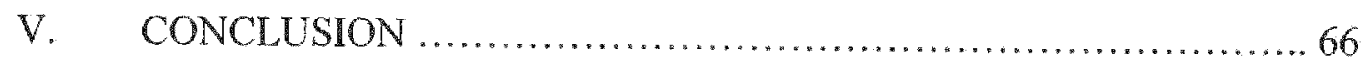

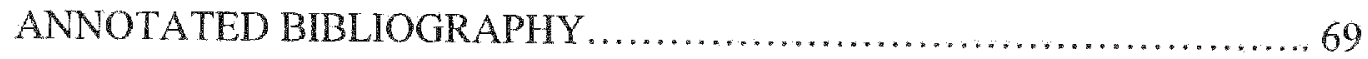


Key to Manuscripts and other Archival Documents Referenced

Bennett, John

BFL Letter to the Bennett family dated 8/3/24. John Bennett Papers - Personal Letters, 1921-1928. 21/140-141. South Carolina Historical Society, Charleston.

Heyward, DuBose

HAL Letter to Hervey Allen dated 7/15/24. Heyward - Personal Papers -

Correspondence - Box 1. 1172.01.01 (A) 01-03. South Carolina Historical Society, Charleston.

IT

Typed transeription of an interview by Selma Robinson of the Literary Guild, no date (though related material is dated 1931). Heyward - Personal Papers - Topical Files. 1172.01.02 (H) 01-08. South Carolina Historical Society, Charleston.

JBL Letter to John Bennett dated 5/13/24. Personal letters - John

Bennett papers, 1176.01.01.21/140-141. South Carolina Historical Society, Charleston.

LN Lecture Notes. Handwritten notes for a lecture on Southern writers. Heyward - Personal Papers - Articles and Related Materials. 1172.01.04.06 (S) 02-01. South Carolina Historical Society, Charleston.

NYP New York Post article. 1172.01.04.03 (P) 01-22. "Cabbage Row's New Dignity." New York Post, Feb. 20, 1928. South Carolina Historical Society, Charleston.

Pm-02 Porgo. ms. 1172.01.04.02(P)01-02 (typed fragments with revisions). South Carolina Historical Society, Charleston.

Pm-04 Porgo ms. 1172.01.04.02(P)01-04 (typed carbon copy). South Carolina Historical Society, Charleston.

Pm-05 Porgy. ms. 1172.01.04.02(P)01-05 (typed ms.). South Carolina Historical Society, Charleston.

PI Introduction to Porgy. 1172,01.04.03 (P) 01-23 (typed introduction to the play), South Carolina Historical Society, Charleston, 1-6. 
RN Research Notes. Notes, typed and handwritten, on ideas for "Negro" stories; and research notes. 1172.01.04.02 (M) 01-01. South Carolina Historical Society, Charleston.

TGQ "Porgy of Catfish Row." 1172.01.04.03 (P) 01-21 Theatre Guild Quarterly, Oct. 1927, South Carolina Historical Society, Charleston, 8-11.

Heyward, Jane Screven.

JH-GN1 ms. 1172.03.01.01-07 (Gullah Notebook \#1). South Carolina Historical Society, Charleston.

JH-GN2 ms. 1172.03.01.01-08 (Gullah Notebook \#2). South Carolina Historical Society, Charleston.

JH-GN3 ms. 1172.03,01.01-09 (Gullah Notebook \#3). South Carolina Historical Society, Charleston, 1923.

JH-GN4 ms. 1172.03.01.01-10 (Gullah Notebook \#4). South Carolina Historical Society, Charleston.

JH-GN5 ms. 1172.03.01.01-11 (Gullah Notebook \#5). South Carolina. Historical Society, Charleston.

JH-GN6 ms. 1172.03.01.01-12 (Gullah Notebook \#6). South Carolina Historical Society, Charleston.

JH-GN7 ms. 1172.03.01.01-13 (Gullah Notebook \#7). South Carolina Historical Society, Charleston. 
"To Smalls I make acknowledgement of my obligation. From contemplation of his real, and deeply moving, tragedy sprang Porgy, a creature of my imagination, [...] and upon whom, being my own creation, I could impose my own white man's conception of a summer of aspiration, devotion, and heartbreak across the colour wall."

\section{Dubose Heyward ${ }^{l}$}

The ability of writers to imagine what is not the self, to familiarize the strange and mystify the familiar, is the test of their power. The languages they use and the social and historical context in which these languages signify are indirect and direct revelations of that power and its limitations. So it is to them, the creators of American literature, that I look for clarification about the invention and effect of Africanism in the United States."

$$
\text { Toni Morrison }{ }^{2}
$$

\section{Introduction}

In light of current reexaminations of the Harlem Renaissance, it is significant to reevaluate texts, and their authors, that may have been overlooked based on limiting definitions of the literary movement. DuBose Heyward's 1925 novel, Porgy, is one such example. ${ }^{3}$ Most people are familiar with Gershwin's famous American folk opera Porgy and Bess, or possibly, Porgy, the original play co-written by Heyward and his wife Dorothy, but not many know of the novel Porgy, from which both works came.

Viewed within a socio-historical framework, the novel, Porgy, with its depictions of the lives, loves, and losses of turn-of-the-century Gullahs in Charleston can be seen as

\footnotetext{
'Heyward is speaking of Samuel Smalls the Charleston beggar who was the real-life inspiration for Porgy. Quote is from Heyward's notes for the Introduction to the play Porgy fully referenced in the Bibliography.

2Toni Morrison, Plaving in the Dark (Cambridge: Harvard University Press, 1992) 15.

${ }^{3}$ For additional reexaminations of texts and authors not generally associated with the Harlem Renaissance, see Women of the Harlem Renaissance (1995) by Cheryl Wall, Double-Take: A Revisionist Harlem Renaissance Anthology (2001) by Venetria K. Patton and Maureen Honey, Eds, and Queering the Color Line: Race and the Invention of Homosexuality in American Culture (2002) by Siobhan B. Somerville.
} 
a work of African American Literary Realism and part of a Gullah literary past. Further, in its careful representation of the Gullah language and culture, its positive portrayal of the Gullah people, and its honest - if somewhat tentative - depiction of race relations in the South, it can also be viewed as a work meeting the thematic criteria of the Harlem Renaissance.

Gullah is the language spoken by Africans and their descendents living in the Sea Islands and coastal areas, situated along the United States' Southeast Atlantic coastline from North Carolina and to Jacksonville, Florida. In the local culture, the name "Geechee" replaces Gullah as a label for the people, and their language and culture. Linguists also refer to the language as "Sea Island Creole." For my study, the term "Gullah" will be used.

From a linguistic perspective, Gullah is one of the Atlantic creoles, (or blended languages), and is the oldest surviving English-based creole in the United States. (AfroSeminole is another English-based creole that remains.) Gullah was developed when Africans from different parts of West Africa were violently uprooted from their homeland, and transported across the Atlantic to the Southeastern United States, whose language was unknown to them. To prevent uprisings, it was a common tactic for slaveholders to mix slaves from different regions and separate tribal or familial groups. Seeking a lingua franca, or a common medium of communication, the enslaved Africans formed a jargon ${ }^{4}$ or pidgin, which later developed into what is classified as Gullah today.

\footnotetext{
${ }^{4}$ In a linguistic context, the term "jargon" refers to a limited, functional language with no fixed forms, unlike a pidgin. For more information, see Holm.
} 
With children born to speakers of this new pidgin language, the linguistic process of "nativization" occurred, wherein this first generation of native speakers created a grammar and formalized the structure of the language, making it a "creole" language. In addition to retaining words and speech patterns from the various African languages spoken by the Africans, Gullah has significant differences from English in syntax, morphology, phonology, and semantics, all of which combine to designate it a unique language. Gullah is not broken English.

The number of speakers of Gullah is dwindling - estimates put it at somewhere between 200,000 and $750,000^{6}$ - and it has often been reported that Gullah is in the process of becoming extinct, caused by a linguistic developmental process known as decreolization. ${ }^{7}$ However, some linguists - notably Salikoko Mufwene - believe that Gullah shows signs of renewed life. Identifying classic American texts such as Porgy as Gullah, and establishing Gullah as part of a rich, linguistic and literary tradition, while there are still native-speakers, is significant to the preservation of the language and the culture.

From a literary perspective, Gullah is the literature written in, by, or about Gullah. It includes the slave stories and legends - from Africa and America, and the accounts of post-war life, fiction and non-, as well as contemporary fiction, memoir and other non-

\footnotetext{
${ }^{5}$ For more detailed explanations of linguistic terms and concepts, see Holm, and Turner.

${ }^{6}$ This estimate is from the National Park Service's three-year study on preserving the Gullah-Geechee culture, completed in 2003 (Burch 1A).

"In the decreolizing process, a language becomes blended with the "lexifier" or the language from which the creole takes its vocabulary, to the point that it is no longer distinguishable as a distinct language. For more information on the linguistic process known as decreolization, see Holm.
} 
fiction. After the mid-Twentieth Century, it is rare to find contemporary work written completely in Gullah. Generally, Gullah, or a "portrayal" of Gullah, is found only in dialogue.

This paper examines a classic text - Porgy (1925) by DuBose Heyward - that has been associated with the Southern Literary tradition. By employing both linguistic and literary analyses, I identify the text as part of a Gullah literary tradition and situate the work within the larger African-American literary tradition, specifically the genre of African American Literary Realism and the period of the Harlem Renaissance. A secondary purpose for this research is to add to the literary scholarship involving Gullah, as it is a subject that has not been studied to any great extent, beyond the linguistic aspect.

The significance of this avenue of inquiry lies in connecting a well-known Southern novelist and playwright, Dubose Heyward, with the Gullah language and culture of his native Charleston, and linking his novel Porgy, (and thus, the more famous play of the same name and the Gershwin opera Porgy and Bess), known for its depiction of African American life in post-war Charleston, specifically with the Gullah people, language, history, and culture that it portrays.

For some, Heyward's position as a white male, on the other side of the "colour wall" from the Gullah people he depicts, raises the issues of the authenticity of his construction of the Gullah, and his authority to act on their behalf in representing them on the written page. It is precisely these kinds of issues - "authenticity" and "authority" that current critical reexaminations of the Harlem Renaissance seek to address. Along with periodization, gender, and geographic boundaries, the idea of "race" as a marker by 
which authentic representation can be constituted is being broken down. It is being replaced with a broader avenue of discourse that looks at the Africanist narrative for the integrity of its representation and its rejection of the long-standing "literary techniques of "othering"" (Morrison 58).

Much as Paul Laurence Dunbar's ill-fated use of black dialect can be seen to have perpetuated negative racial stereotypes, Heyward's respectful representation of the Gullah language may be seen to dispel them. By making the language accessible to a non-Gullah audience, Heyward allows us to cross over "the colour wall" and see beyond the stereotypes. It must be noted however, that Heyward's position as a white male made him more socially and politically able to present his view. He had access to the whitecontrolled publishing world and while he may have been rejecting "othering," it was his white readership's interest in the exotic black "other" that insured the book's success. Dunbar, on the other hand, was far less assured of his foothold in the white publishing world and all too aware of it resting on the dialect poetry which pandered to whites' racial stereotypes of blacks.

Heyward's novel Porgy seeks to give voice to an unpropertied, illiterate, and disenfranchised majority: the Gullah people at the turn of the century in the South. In his efforts to make the language and the culture familiar, and not foreign, Heyward is attempting to "make the white written text speak with a black voice" (Gates 131). He is creating a Gullah literary persona and in doing so, he is bringing them into the discourse. Speaking of Ernest Hemmingway and how removed from African-Americans his work is, Toni Morrison notes that "he has no need, desire, or awareness of them either as readers of his work or as people existing anywhere other than in his imaginative (and 
imaginatively lived) world" (Morrison 69). Heyward, on the contrary, was driven to present the Gullah realistically and to show his admiration for their rich history and culture.

Gullah, with its origin as the language of the slaves and the resulting connection with illiteracy, was long viewed as broken English, and its use was, at best, considered "quaint" or "colorful," but more often, a sign of being uneducated and backwards. These negative connotations have contributed to Gullah not being recognized as both a distinct, culturally significant language and as the primary root of modern-day African-American English varieties.

When surveying what has been written on Gullah - the language, the people, the history, the culture - the bulk of the findings fall into two categories: 1) linguistic studies of Gullah as a creole language, and 2) cultural and historical studies of Gullah traditions, beliefs, foods, and handicrafts.

In the first category, the preeminent work is Lorenzo Dow Turner's Africanisms in the Gullah Dialect. ${ }^{8}$ Published in 1949, after decades of research, Turner's book successfully argued that Gullah was indeed, by definition, a true creole language, with some 4,000 Gullah words and names directly linked to their West African counterparts. He performed a thorough analysis of Gullah using established linguistic criteria such as: phonetics; diacritics; syntax; and morphology, and produced an organized and detailed record of the language. He also discovered linguistic and cultural patterns that were

\footnotetext{
${ }^{8}$ Lorenzo Dow Turner, Africanisms in the Gullah Dialect (Chicago: University of Chicago Press, 1949).
} 
traceable to various African cultures and that debunked the notion that Gullah was merely "bad English."

Turner's work remains the standard-bearer in Gullah linguistic studies and he has inspired others to study Gullah. Later scholars such as Florida International University's Tometro Hopkins, the University of South Carolina's Michael Montgomery, the late Patricia Jones Jackson, and Salikoko Mufwene have picked up the torch lit by Turner and added to the linguistic scholarship on Gullah.

Aside from linguistics, most of the writing on, and sometimes in, Gullah, falls into the areas of historical, anthropological, or sociological study, and as expected, it covers a wide variety of topics. Gullah history begins some 400 years ago when the first African slaves were brought to the American colonies via the Caribbean, and most of the pre-Civil War Gullah history exists only in "outline form" through plantation records and slaveholder accounts, as slaves were not allowed to be taught to read and write. Cultural traditions such as grave marking, herbal cures, "conjuring" or practicing "root" medicine (magic), religious rituals, music and singing, naming, basket-weaving, net-making, burial rites, folktales, the use of parables as morality lessons, kinship networks, and food preparation, are just some of the many practices studied and written about by post-war historians, and anthropologists, and appearing in accounts by former slaves.

Roosevelt's Depression-era Works Projects Administration created jobs for unemployed writers who conducted extensive interviews with ex-slaves in the South and recorded their oral histories and responses to specific questions about their beliefs, 
customs, traditions, and rituals. ${ }^{9}$ These Gullah-associated customs, beliefs, and traditions can be examined as markers of Gullah presence in the literary work. Their presence or absence speaks to the accuracy of the portrayal of Gullah history, culture, and social customs and relationships.

Because Gullah is a spoken language without a written form, and its original speakers were largely illiterate, the first works of Gullah literature were either "as told to" slave narratives or "nostalgic accounts by low country whites" (Montgomery xlvii), which included appropriations of Gullah folktales and "portrayals" of Gullah speech, such as the well-known "Uncle Remus" stories by Joel Chandler Harris. "Low country" is the term used to refer to the coastal region of South Carolina including Charleston and Beaufort, along with the Sea Islands.)

Though Gullah is generally recognized linguistically as a unique language, there has been no literary scholarship on what constitutes Gullah literature, and little recognition of its place in the larger genre of African-American literature. Without such study, many texts, like Porgy, might not be identified and claimed as part of a Gullah literary tradition.

The theoretical framework with which to critically approach Gullah literature has only been around for approximately 20 years. In the early Eighties, Houston A Baker Jr. laid the groundwork for African-American literary theory with his book Blues, Ideology, and Afro-American Literature: A Vernacular Theory (1984), connecting the idiosyncrasy of the blues riff with the railroad crossing as a site of discursive juncture. He followed it

\footnotetext{
${ }^{9}$ The University of Georgia published the collection of interviews conducted by the Savamnah Unit of the Georgia Writers' Project / WPA as Drums and Shadows, (University of Georgia Press, 1940).
} 
with Afro-American Poetics (1988). In 1986, Geneva Smitherman Donaldson added her voice with Talkin' and Testifyin', looking at contemporary examples of black vernacular for the rhetorical traditions such as signifying, call-and-response, co-signing, and punning. Henry Louis Gates Jr. delved into the African rhetorical heritage of black vernacular and defined a specifically literary theoretical approach based on the black vernacular in his work The Signifying Monkey (1988).

Gates looked at various African gods and characters associated with myths and legends for sources of typically African modes of discourse, such as the African trickster figure representative of the Yoruba god, Esu, or Elegba. Esu is known for trickery and indirection, for ambivalence, and is associated with communication and the crossroads. Gates studied African American texts from the slave narratives to contemporary fiction and identified specifically African American vernacular traditions such as "signifyin(g)" (Gates 90), parody, and naming, and their roles in African American literature and discourse. He theorized that the vernacular traditions become literary tropes as the oral tradition of African American culture develops into a written voice.

Gates and the other critics discuss African American Vernacular English (AAVE) and Black Vernacular theory, and identify the established rhetorical patterns and their significance to African-American culture and literature. As the Gullah language is one of the primary roots of AAVE, these discussions provide the framework for situating the novel Porgy within the African-American literary tradition.

As part of that tradition, the language and the people/culture are inseparably interwoven in Gullah literature. Thus, it is imperative to analyze both Porgy's Gullah dialogue and the text's descriptive narrative looking for the linguistic and literary markers 
that connect Porgy to the Gullah language and people/culture. Connecting a classic American text and its grander affiliates - the play Porgy, and the classic American folk opera Porgy and Bess - with Gullah, and hence, with African American literature, provides a critical interjection in the established discourse of Southern Literature. Further, close examination of the text and its literary themes and stylistic features clearly show that Heyward's text meets the criteria for inclusion in the genre of African American Literary Realism, and thematically anticipates the Harlem Renaissance.

The characteristics of the realistic novel and the genre, African American Literary Realism, include the construction of a realistic slice of black life through the use of black dialect or folk speech, specific markers of time and place, the inclusion of local customs and practices, and the creation of black characters who are ordinary people with faults and weaknesses. Porgy"s realistic depiction of the daily lives of Charleston's Gullah community at the turn of the $20^{\text {th }}$ Century meets all of these criteria. Though he was geographically removed from Harlem, Heyward's use of Gullah and African American vernacular forms such as the spirituals, the positive racial identities he creates, his depiction of the characters' self-reliance - individually and as a collective black community -, all anticipate the literary features and themes that would dominate the Harlem Renaissance, and would later become "the building blocks of African American modernism" (Wall 12).

The naming or reclaiming of Gullah literary works such as Porgy is part of what educational theorists Paulo Freire and Donaldo Macedo refer to as "critical literacy" or the idea of using "language for social and political reconstruction." Literacy "becomes a vehicle by which the oppressed are equipped with the necessary tools to re-appropriate 
their history, culture and language practices." 10 Identifying Porgy as part of a Gullah literary heritage paves the way for greater recognition of the literature that Gullah inspired, and for which it served as the subject, setting, and the voice.

Early versions of Heyward's manuscripts, along with his papers and correspondence, are located in Charleston at the South Carolina Historical Society. In addition, the collected writings and papers of his mother, Jane Screven (DuBose) Heyward, are there, and as her influence on her son was strong, they contributed greatly to the research. This availability of primary documents and the ability to do archival work made for exciting research possibilities and provided clear evidence of Heyward's sociohistoric connection to Gullah culture and his exposure to the language. His letters, research and lecture notes yielded much information as to Heyward's inspiration and motivation in writing Porgy and the basis for many authorial decisions he made.

${ }^{10}$ Freire and Macedo quoted in "Dismantling "The Master's House:" Critical Literacy in Harriet Jacobs" Incidents in the Life of a Slave Gir" by Martha J. Cutter. Callaloo, 19.1 (1996), 209-225. 
II. Literary Realism, Black Vernacular, and African American Literary Theory

On the surface, Charleston native DuBose Heyward may have looked like the last person likely to write a realistic work of fiction dealing with the lives of the black residents of Charleston's Gullah community in the early part of the Twentieth Century. Yet, his 1925 novel Porgy is a work that, in many ways, answered the call put forth in the $1890^{\prime}$ s by black leaders and intellectuals such as W.E.B. Du Bois, H.T. Johnson, and W.S. Scarborough for accurate portrayals of black speech presented without mockery, and for fully fleshed-out black characters with hopes and dreams, flaws and foibles. Heyward took great pains with the Gullah language and his portrayal of Gullah life and Porgy's achievement of these representational goals is evident in the continuing popularity of the work's most famous offspring, the folk opera Porgy and Bess, and renewed interest in Heyward as its author." A closer examination of Heyward's life, his influences, and his own words, reveals that he may, in fact, have been born to the task.

Until the latter part of the nineteenth-century, the history of African American literature was largely one which foregrounded the slave narrative. ${ }^{12}$ After the Civil War and Reconstruction, American literature moved away from romanticism and toward a realistic aesthetic. With the rise of realism, the slave narrative took on new forms as well. Booker T. Washington's Up From Slavery was published in 1901 and the school of

\footnotetext{
"In 2000, DuBose Heyward: A Charleston Gentleman and the World of Porgy and Bess, a new biography of Heyward, was published, followed by A DuBose Heyward Reader, both by James M. Hutchisson.

${ }^{12}$ Notable exceptions exist: Phyllis Wheatley's Poems on Various Subjects Religious and Moral (1773), William Wells Brown's Clotel (1853), and The Garies and their Friends (1857) by Frank J. Webb.
} 
Tuskegee Realism was born. With its emphasis on facts and its view of language as nothing more than "a referential medium" (Andrews 86), Washington's version of realism countermanded the very core of black rhetoric, which was built on the specific forms and strategies of the black vernacular tradition such as signifying, parody, and the rich use of metaphors and similes.

In reaction, some black authors began to signify on the slave narrative itself. Frances Ellen Watkins Harper's Lola Leroy (1892), a "protest romance" (Andrews 87) tropes on Frederick Douglas' famous narrative. Charles W. Chesnutt's The Conjure Woman (1899) is a work of fiction presented as the realistic autobiography of a white man who recounts slave narratives told to him by an ex-slave. A far cry from Washington's demand for realism, The Conjure Woman is clearly signifying on the plantation stories told by ex-slaves in the popular works of white authors like Joel Chandler Harris.

James Weldon Johnson signified on the white authors themselves with The Autobiography of an Ex-Colored Man (1912), in which his fictive black author chronicles his life and his ultimate choice to pass and live as a white man. In his article "The Representation of Slavery and Afro-American Literary Realism," William L. Andrews says that works like The Conjure Woman and The Autobiography of an Ex-Colored Man served to "decertify [...] the 'real, solid foundation' on which Tuskegee Realism claimed its hegemony" (87). This decertification opened the door for a move away from the factual reality of the slave narrative and made way for the realistic novel. Washington was concemed with establishing African Americans as authors and his Tuskegee Realism demanded fact-based narratives. Authors like Chesnutt and Johnson freed themselves 
from the social responsibility of refuting white stereotypical notions of black subjectivity by creating realistic novels that were uniquely African American.

Meanwhile, in poetry, the use of black dialect was popular in the late $19^{\text {th }}$ Century. It was most prominent in the poetry of Paul Laurence Dunbar. Dunbar wrote poems in both standard English and black dialect, and published fairly extensively between 1893 and 1905. His dialect poems were both profitable and popular and he was widely imitated. However, Dunbar was criticized by black critics such as James Weldon Johnson for pandering to white audiences and playing to racist stereotypes of blacks. Johnson himself had initially written poems in black dialect but he turned away from the practice and condemned it. Later, Johnson softened his position somewhat, though it was too late for Dunbar who died in 1906.

In the 1923 Preface to The Book of American Negro Poetry, edited by Johnson, he called for black writers to "break away from, not Negro dialect itself, but the limitations of Negro dialect imposed by the fixing effects of long convention [...] it is an instrument with but two full stops, humor and pathos" (qtd. in Gates, 177). The anthology included some early poems of Langston Hughes, a poet who would become a dominant figure in the Harlem Renaissance and who used black dialect to great effect in his work. By the time of the anthology's second edition in 1931, largely due to the poetry of Hughes and Sterling A. Brown, Johnson was forced to acknowledge and applaud dialect that reflected the "common, racy living speech of the Negro in certain phase of real life" (qtd. in Gates 177). In the literary climate of social realism, dialect became a powerful tool, when it was used to add authenticity, and not merely for comic effect. 
The use of black dialect to add realism, rather than for entertainment, was only one marker of the Harlem Renaissance. Defining the term "Harlem Renaissance" itself can be problematic. It can be seen variously as: a particular literary "moment" (or period) that existed, arguably, from the mid-1920's through the mid-1930's; a particular geographic and historic literary locale which influenced many writers and provided the setting for many literary works; or a thematically-linked body of literature. The claiming or re-claiming of black dialect and thetorical devices for use in the realistic portrayal of black characters and black lives, is both an act of signification and an important step forward in African American literature.

The Harlem Renaissance fostered a renewed interest in dialect poetry and Heyward had early success. Contemporary Verse published his first poem dealing with black life, "Gamesters All," in 1921 and the poem won the journal's annual prize (Hutchisson 34). The poem described an illegal craps game and the shooting of a fleeing black man by the white sheriff, and it "suggests Heyward's feel for black speech rhythms and his interest in incorporating jazz and blues into poetry" (Hutchisson 35).

"Gamesters All" also contained the seeds that would grow into the novel Porgy a decade later.

Noted editor and critic William S. Braithwaite, himself a poet of some renown, recognized Heyward's talent and was supportive. He selected "Gamesters All" for inclusion in his annual Anthology of Magazine Verse and Yearbook. When Heyward's book Carolina Chansons was published in 1922, Braithwaite sent Heyward a complimentary review blurb. Heyward forwarded it to the editor of a regional paper for possible use in advertising for the book. The editor wrote Heyward that it was "not 
advisable" to print the comments of an African American, no matter how well known he might be in the North (Hutchisson 45). Heyward's naiveté must have been confusing to white Southerners who saw him as the stereotypical Charleston gentleman.

Although Heyward was raised in the insular world of Charleston and its environs, and was somewhat provincial, it seems certain that his reading and research took him far beyond the borders of the South. His work with the Poetry Society required him to keep abreast of the current American poets. In his handwritten notes for a "Negro article,"13 presumably prepared after Porgy's publication ${ }^{14}$ when Heyward was a sought-after lecturer on Southern literature and black life, Heyward lists most of the top black poets and writers of his day. He writes: "It is indeed a pleasant thing to turn from the Negro as a problem - as someone to be decided about - and to consider him as a literary artist..." (LN, 6). Under "Poetry," he includes Countee Cullen, Claude McKay, Langston Hughes, Jean Toomer, William S. Braithwaite, and James Weldon Johnson. On the other pages, he outlines a retrospective of $20^{\text {th }}$ Century African American writers, and those writing on African Americans, broken down into categories.

Heyward list includes writers of both prose and drama, and it appears that he intended to discuss both African American writers and the various treatments of the African American as literary subject. Under "folklore" he notes the "divisions" of

13 Heyward wrote "Negro article" on the top edge of page one, but the six handwritten pages are catalogued as "Lecture Notes on Southern Literature" in the Heyward Collection at the South Carolina Historical Society in Charleston and they are fully referenced in the Bibliography.

14 A note makes reference to a page that does not appear saying "See page $5 / \mathrm{New}$ Negro for names of New Negro writers and their methods" (LN). As the "New Negro" is a reference to Alain Locke"s 1926 The New Negro, this indicates that these article or lecture notes were written sometime after 1926. 
"Negro" and "white," and under the heading "Whites on Negro" he further subdivides the category into "serious" and "comic." He lists folklore writers Joel Chandler Harris, Ambrose Gonzales, and T.W. Tulley. Under "Fiction" he writes "Chas W. Chestnutt (sic) The Conjure Woman, George Washington Cable Old Creole Days, Waldo Frank Holiday, Jessie R. Fauset There is Confusion, Emmett R. Kennedy Black Cameos, Julia Peterkin Green Thursdoy, T.S. Stribling Birthright, Jean Toomer Cane, Walter F. White Fire in the Wind, Clement Wood Nigger," and "Nigger Heaven" (by Carl Van Vecten).

In addition to poetry and prose, Heyward was interested in drama. Besides marrying the playwright, Dorothy Kuhns (Hutchisson 50), with whom he wrote the play Porgy, Heyward collaborated on the folk opera Porgy and Bess, and wrote for film. Heyward wrote the screenplay for the 1931 film The Emperor Jones from the 1920 play by Eugene O'Neill (Hutchisson 127). Among the playwrights he lists in his lecture notes are Eugene $\mathrm{O}^{\prime}$ Neill, Paul Green, T.W. Tulley, Ridgely Torrence, and William R. Rogers Jr. Heyward's list of writers encompasses both Southern and Northern writers of both races and genders, and is a representative cross-section of the contemporary writers in African American literature and drama of the early $20^{\text {th }}$ Century.

After the Civil War, the shift towards realism was seen on the stage as well as in literature. Plays began to revolve around working class characters and accordingly, dialogue moved toward realistic portrayals of speech. In the 1920 's, serious African American characters - not the servants and simpletons depicted in the minstrel and vaudeville traditions - began to appear in plays, and with them came the use of a more accurate approximation of black dialect. 
However, throughout most of the 1920's, white actors still played most African American roles on stage. O'Neill's Broadway production of The Emperor Jones in 1920 was one of the first plays on Broadway to feature a black actor in the lead role and a cast with actors of both races. Seven years later, Broadway was still not integrated.

Heyward's play Porgy was among the first to appear with black actors in all of the black roles, at the insistence of Heyward and his wife Dorothy, who would not allow it to be staged otherwise (Hutchisson 76).

In the 1920's, African American musicals on Broadway were generally minstrelstyle revues, and in keeping with the novel's realism, Heyward sought a more authentic and respectful approach when he brought Porgy to the stage. "It is a far cry from the music and dancing of 'Shuffle Along,' 'Runnin' Wild,' and the coloured Night Club Revue, (sic) to the spirituals, with their depth and sincerity..." wrote Heyward in the typed Introduction for the play Porgy. (Runnin' Wild was the musical revue that debuted "the Charleston" dance craze in New York in the early 1920's.)

Heyward's awareness of other writers and what they were doing with dialect and representations of African American life and culture likely contributed to his intense desire for accuracy in his own work. He certainly knew of the criticism Dunbar and others had received for gratuitous use of dialect that seemed to play to racist stereotypes, as well as criticisms of some Southern writers for their inaccurate portrayals of black dialect. Thus, he took great care with the Gullah dialogue in Porgy, specifically with his written representation of it.

Heyward recognized that the Gullah language was an integral part of the Gullah character, just as language in general is an important part of the black cultural tradition of 
expression. Black vernacular, with its similes and metaphors, its rhythms and tropes, what Cheryl Wall calls "the poetry of black vernacular expression" (142) - is part of "an American vernacular ancestry" (Baker 200). Verbal dexterity is prized within the black community. From "tellin" the lie" (a euphemism for storytelling), to "playin' the dozens" (a back-and-forth game of verbal insults), to the oratorical style of the sermon, rhetorical skills are elevated to an art form and the power of language is celebrated.

Heyward was interested in the specific vernacular form of the spirituals and he used them throughout Porgy. He refers to them as being "as much a part of the daily life [...] as breathing" (PI). He recognized the communal nature of the spirituals. He depicts them as arising spontaneously from individual fear or grief, but the feeling is taken up and others share the burden. During the hurricane, the residents of Catfish Row huddle together in the building's old balliroom:

"Then someone started to sing: "I gots uh home in de rock, don't yuh see?"

With a feeling of infinite relief, Porgy turned to his Jesus. [...] He lifted his rich baritone above the others: [...] 'I gots uh home in de rock, Don't yuh see!' Then they were all in it, heart and soul" (151-152).

The public voicing of emotion was in stark contrast to the idea of keeping feelings private and practicing public reserve and decorum, characteristic of the Anglo-American.

Heyward was aware of the strong sense of connection and community possessed by the Gullah, and its absence in the parallel white community. He wrote: "... in their work and play it is the mass rhythms, the concerted movernents, the crowd laughter, the communal interrelationships of the Negro quarter that differentiate it most sharply from its white slum neighbor" (PI). It is this sense of connection that unites the blacks against 
the whites whenever the whites, generally in the form of the law, intrude into the sanctum of the inner court of Catfish Row,

The Gullah inhabitants of the Row instinctively close ranks against the white intruders and collectively participate in impromptu dramas intended to deceive the whites and protect the members of the black community. They live by an unwritten code that does not permit giving up one of their own to the white authorities, no matter how heinous the crime. Although Crown has murdered her husband and left her a penniless widow with three small children to raise, Serena won't give him up to the police, despite the fact that she could face jail herself. As the grieving widow, she will be the number one suspect in the event that anything happens to Crown, but the code of racial solidarity is stronger than her fear.

Heyward's makes a number of observations about race relations in his depictions of racial interaction in Porgy, but he avoids engaging in direct social commentary on race. Besides the various scenes where the police come to the Row in search of witnesses or suspects and the residents are alternately unhelpful and deceitful, he presents several interactions between black and white individuals. In these scenes, he depicts Southern blacks and whites as knowing and understanding each other. When the white lawyer, Archdale comes to the Row looking for Porgy and the residents engage in a ritual behavior known as masking and designed to "mask" their intention to deceive, Archdale is fully aware of what is happening. Heyward writes: "The white man laughed reassuringly, as though quite used to the proceeding" (58). Archdale has clearly experienced this behavior before and knows that it will persist until he satisfies the black residents of the Row that he means Porgy no harm. 
Similarly, Porgy is cognizant of the ways of the Southem white aristocrat.

When Archdale objects to the presence of Porgy and his smelly goat setting up shop on the doorstep of his law firm, Porgy knows exactly how to manipulate Archdale to get his way. The Gullah lawyer, Frasier - there to discuss his own trouble with Archdale snobbishly tells Porgy he better move. Knowing that Archdale can hear him, Porgy makes his play:

"His voice rose to a pitch of indignation: 'Yuh might be a lawyuh, an' all dat; but I ain't goin' tuh hab yuh stan' dey an' tell me dat Mistuh Archdale gots dem po' wite-trash ways. Ob course he don't likes de smell ob goat; but he gots er haht in he breas' fuh de po' cripple nigger." A wry smile tugged at the corner of Archdale's mouth. "All right, Porgy," he said, "I got it all; but, gentleman or no gentleman, I can't have a goat on my doorstep. I would not have one client left in a week' (71).

By invoking Archdale's sense of noblesse oblige and amusing him, Porgy wins.

Heyward showcases the connection between the races in their united dislike of the Northern carpetbaggers who descended upon the South during Reconstruction. In Porgy, Heyward presents a subplot to the story wherein the Gullah lawyer Simon Frasier is in danger of being indicted for his practice of granting divorces for the Gullah using a made-up divorce decree. Archdale intercedes with the appointed Yankee solicitor on Frasier's behalf. Archdale and Frasier's resentment of the intrusion is evident in the way they refer to the solicitor. Archdale calls him "the gentleman who has come down to improve moral conditions among the Negroes" (73) and Frasier calls him "the sof mout" gentleman" (73), evidently a reference to his lack of character. 
This scene's significance lies in Heyward's depiction of the way the races lived side-by-side but separately, with different practices and lifestyles, and a seeming acceptance of each other. However, this acceptance was contingent on people not challenging the color line. When Archdale examines a copy of one of Frasier's decrees, his reaction is matter of fact. He says: "Well, that is simple enough. Where did you get this seal?" (73). He is not outraged at the lack of moral turpitude, which is evidently the reaction of the Yankee solicitor who has threatened to jail Frasier. Similarly, Frasier does not see the problem; he recognizes that it is against the law but he sees the law as being for white people and not relative to blacks.

It is interesting to note that Archdale's duplicity and manipulation in dealing with the Northern solicitor, Mr. Dennis, mirrors the way Porgy and the other Gullah people have dealt with him (Archdale). When Archdale calls Dennis, he first attempts to downplay the case, pointing out its relative insignificance in light of the court's heavy docket. He continues: "There is no use taking the State's money and your valuable time on this case" (75). Ironically, his use of flattery to manipulate Dennis is just like Porgy's tactic with him a few moments earlier. And like Archdale, Dennis evidently recognizes that he is being toyed with, and he objects. Archdale quickly continues: "Oh, no: I am not trying anything" (75). He then changes tack and refers to Frasier as old, indicating that he is harmless: "... no one takes old Frasier seriously" (75) and agrees to take personal responsibility for seeing that Frasier ceases the practice. The "we take care of our own" attitude depicted in this scene is condescending but realistic.

Clearly, Heyward shrinks from tackling the complete reality of racial relations and segregation in the South. This depiction of black and white Southerners as being 
able to handle their own problems and being united in their shared resentment of Northern intrusion reads somewhat like a Civil War era apologia. In his book Black and White Strangers: Race and American Literary Realism, Kenneth W. Warren addresses the idea of "fiction's responsibility for or opposition to the social order that took shape during the post-Civil War years" (1). He concludes that "the novelistic consciousness couples a disdain for class barriers with a belief in a quasi-democratic distribution of talent, potentially paving the way for an argument on behalf of the social rise or inclusion of previously excluded groups" (25). Thus, while Heyward does not foreground the issue of race, in presenting it he is subtly challenging the status quo and setting the stage for discourse on racial equality.

Although Heyward was not overtly political, and in his later writings about Porgy, he did not make reference to any particular social agenda or intention, he knew he was doing something new when he wrote Porgy. In the summer of 1924 , he wrote his friend John Bennett about his work in progress, but he swore him to secrecy. Heyward wrote: "It is still so experimental; I am just feeling it out [... I I have not hesitated to tum on the spotlight. If it comes through, it will at least not be pap" (qtd. in BFL). Heyward was aware of what other writers and poets were doing in prose and poetry, and he also had a keen awareness of his own world.

In his portrayal of the Gullah people as individuals with wit, intelligence, resilience, tenacity, loyalty, and a full range of human emotions, Heyward responds to W.E.B. Du Bois' reminder of our shared humanity in his 1903 epic The Souls of Black Folk. Du Bois says that justice demands that we not "forget that each unit in the mass is a throbbing human soul. [...] it loves and hates, it toils and tires, it laughs and weeps its 
bitter tears, and looks in vague and awful longing at the grim horizon of its life, - all this, even as you and I" (qtd. in Warren 27). Heyward's goal as an artist is to open the door to the Gullah world and invite us inside, in the hope that we will recognize ourselves therein. 


\section{The Gullah Language in Porgy - a Linguistic Analysis}

Perhaps the most interesting aspect of Gullah in Porgy is Heyward's representation of the language. In order to create a realistic portrait of the Gullah people, Heyward knew it was essential to incorporate the use of the Gullah language into the novel in the form of dialogue. However, as a published writer of some renown, Heyward was writing for a national audience, one that would not understand many of the Gullah words, and would be lost without conventional American English sentence structure. Thus, he sought to find a balance between linguistic accuracy and linguistic accessibility. Original handwritten manuscript fragments of the play Porgy, ${ }^{15}$ which was initially written by Dorothy Heyward and then collaborated on by DuBose Heyward, show dialogue of the Gullah characters that is not particularly Gullah and not like the dialogue of the Gullah characters in the novel Porgy or its early manuscript versions. Though she wrote the original draft script for the play Porgy from DuBose Heyward's novel, adding much dialogue, Dorothy was from Ohio and not familiar with the Gullah language. It is reported that DuBose rewrote the dialogue, making it "somewhat slangier" (Hutchisson 76). He made extensive revisions focusing on making the dialogue as authentic as possible while making it comprehensible to non-Gullah, and nonSouthern, audiences. The Gullah dialogue of Porgy became, in effect, "a translation" (Dorothy Heyward, qtd. in Lavely 127).

\footnotetext{
${ }^{15}$ These materials are part of the Heyward Collection located at the South Carolina Historical Society in Charleston. They are fully referenced in the Bibliography.
} 
It is interesting to note that fifty years after Heyward's death, a "Gullah version" of the play Porgy was produced, or translated, by Virginia Mixson Geraty. ${ }^{16}$ Geraty's intention seems to have been to set the record straight linguistically, but in doing so, she highlights precisely why Heyward could not have written the dialogue completely in Gullah. Geraty's work is published by a small local press in Charleston and is not likely to have achieved any significant sales outside of Charleston. Non-Gullah speakers, or at least those unfamiliar with the dialect of the American South or the English creole dialects of the Caribbean, would have difficulty comprehending the Gullah dialogue as it appears in Geraty"s version of the play Porgy.

Despite his familiarity with Gullah, Heyward struggled with his representation of the Gullah dialogue in Porgy. The greatest difficulty of course, was that he was working with a spoken language that had no written form. Though others had published literary representations of Gullah before, there was no standardized orthography. Frank Durham, an early biographer of Heyward, reported that Heyward wrote with charts showing the English and Gullah equivalents of words displayed in front of him (Haskell 31 ). Presumably, Heyward made these charts himself, with the likely assistance of his mother Janie, whose firsthand knowledge of the language was much greater than his.

Examination of early, typed fragments of the novel with handwritten revisions, and two typed manuscript versions of the novel, ${ }^{17}$ reveals the many changes made by Heyward to the dialogue of the Gullah characters. In contrast, there are no changes made

\footnotetext{
${ }^{16}$ Virginia Mixson Geraty, Porgy: A Gullah Version (Charleston: Wyrick \& Company, 1990 ).

${ }^{17}$ These materials are part of the Heyward Papers located at the South Carolina Historical Society in Charleston. They are fully referenced in the Bibliography.
} 
to the dialogue of the novel's white, non-Gullah characters. Although Heyward's educated, white characters, like the lawyer Alan Archdale, the coroner, and the judge, speak a more standard form of English than that of the working class whites, like the policeman, and the apothecary, multiple versions of the manuscript show no changes whatsoever to any of the dialogue of any of the novel's white characters. Similarly, there are only minimal changes in the descriptive narrative portions of the two manuscript versions, and the typed fragments.

Heyward's careful choices and painstaking revision of the Gullah dialogue in Porgy show his desire to create a realistic portrayal of the Gullah people and their lives in post-Reconstruction Charleston. In addition to his concern with the language itself, Heyward also shows his knowledge of Black vernacular speech patterns and rhetorical styles, and the realistic depictions throughout Porgy indicate more than a passing acquaintance.

In representing spoken Gullah, Heyward had a number of different models on which to draw - William Gilmore Simms, Joel Chandler Harris, Charles C. Jones, Jr., Ambrose Gonzales, his friend, John Bennett, and his mother, Jane Screven Heyward - all of whom had published works with Gullah dialogue prior to Heyward's writing of Porgy. However, it is notable that all of these writers, while perhaps hoping for a national audience, were primarily publishing works for a Southern audience, one that would be reasonably familiar with Gullah. Even Joel Chandler Harris, whose Uncle Remus tales eventually achieved an international audience, initially wrote them for publication in the Atlanta Constitution, the newspaper for which he worked. Accordingly, these authors could take more liberties with their representations of the Gullah language. Their 
Southern readers could be counted on to recognize the intended pronunciation and to be familiar with words and expressions particular to Gullah. Heyward, however, wrote Porgy for a national audience and he knew that his treatment of the Gullah language was important. He needed to convey the feeling to the readers that they were "hearing" Gullah, in the dialogue of the Gullah characters, in order to transport them into the world of Porgy. On the other hand, he had to make the dialogue readable to achieve this goal. Creating a sense of realism was key to the novel's success.

Being well-read, a published poet, and co-founder of the nationally recognized Poetry Society of South Carolina (in 1921), Heyward was aware of what other American writers were doing with black dialect. At that time, essentially all black dialect was Gullah. As a Southern child, Heyward was certain to have been familiar with Joel Chandler Harris, writing of the Georgia Geechee or Gullah people with his Uncle Remus animal tales and plantation stories. As a poet, Heyward surely read the poems of Paul Lawrence Dunbar, whose use of black dialect in the late $19^{\text {th }}$ Century won Dunbar popular success and critical acclaim. In 1922, James Weldon Johnson published The Book of American Negro Poetry, considered by some as the text that heralded the start of the Harlem Renaissance. It included the poems of Langston Hughes, who became one of the movement's leading figures. Hughes' use of black dialect and jazz idioms - to great effect - undoubtedly influenced Heyward, though Heyward had experimented with the form ten years before writing Porgy.

In his portrayal of the Gullah language Heyward chose to focus on the "sound" of spoken Gullah, with its colorful expressions and use of word phrases, and though the 
Gullah of his dialogue is far from "pure,"18 (so much so that linguistically speaking, it can't truly be considered Gullah), he retained many of the linguistic markers of the language, such as the use of the non-gendered pronoun, the idiomatic language or calques, and the uninflected verbs. However, like writers before him, Heyward too, made assumptions about Gullah word origins that led him to include marks of omission, specifically the apostrophe, to indicate places where he thought English sounds (phonemes), and the letters that represented them, had been omitted. The inclusion of these marks of omission was in keeping with the predominant thinking of the time, that Gullah was really English, just poorly pronounced and greatly simplified.

In addition to his efforts to reproduce the phonology or the sound of Gullah, Heyward put similar effort into the lexical, morphological, and syntactical features of Gullah. In dealing with all aspects of the language however, Heyward had to make choices about how to balance his desire to accurately represent the Gullah language with the need to make the language accessible to a primarily non-Gullah audience. It was often necessary for him to forgo accuracy in favor of making the dialogue comprehensible. It is Heyward's linguistic and literary choices that open a window into the world of Charleston's Gullah community at the turn of the century.

\section{Intonation}

One of the more obvious phonological or sound differences between standard American English and the creole language, Gullah, is in the area of intonation.

\footnotetext{
18 "Purity," in terms of language authenticity, is a problematic concept. Linguists use the terms "basilect" (the deepest form of the language) and "acrolect" (the form that is closest to the lexifier, or English, in the case of Gullah) and refer to language continums. For a more complete discussion of language continuums, see Jones-Jackson and Mufwene.
} 
Compared to Gullah, English is largely atonal and the patterns of intonation that are used (for example, rising or falling tones at the end of sentences like questions or exclamations) are often completely opposite of those heard in Gullah. As a creole language with ancestral roots in a number of West African tone languages, Gullah has a distinct and complex intonation system that is a key component of the spoken language. This is the aspect of Gullah that is frequently described as its "rhythm." Without using linguistic symbols however, intonation is difficult, if not impossible, to indicate in written language and Heyward did not attempt to capture this aspect of the language on paper. ${ }^{19}$

\section{Phonology}

The most obvious examples of the literary re-creation of the sound - or phonology - of Gullah in Porgy are the changes to standard English orthography that Heyward makes to represent sound substitutions and omissions. When Heyward changes the dialogue of the Gullah character Bess as she answers the judge in court from "No sir" in the early manuscript (Pm-04, 60) to "No, sub" in Porgy (88), the sense of realism is heightened. We do not expect Bess to "sound" like the white court officers or the judge. The change also allows us to "hear" Bess' submissive tone-sincere or mocking as it may be - and this is reinforced later in the passage when she calls the judge "Boss" $(90)$, a form of address that remained from slavery days. Clearly, Heyward's orthographic choices are crucial to his representation of the Gullah people and the numerous changes that exist between the various manuscript versions of Porgy attest to this.

\footnotetext{
${ }^{19}$ To accurately depict the intonation patterns of a language requires either an auditory explanation or the use of sophisticated linguistic marks for high-, mid-, and low- tones, along with falling and rising ones. For a detailed linguistic discussion of Gullah's intonation patterns, see Turner.
} 
Some of the orthographic changes or "re-spellings" (Haskell 231) appear to be Heyward's attempts to fine-tune his choices in representing spoken Gullah, such as the revisions of "yer" to "yuh," "ter" to "tuh," and "atter" to "attuh" Interestingly, these initial spellings - "yer," "ter," and "atter" - are the ones used by Heyward's mother, Jane Screven Heyward in her own representations of the Gullah language, found in her collected notebooks of Gullah history, stories and anecdotes (JH-GNH1-7) ${ }^{20}$ It is evident that Heyward tumed to his mother's work as a model for his early orthographic decisions but he made revisions based on his own ear and the national audience he intended for Porgy.

An example of sound substitution in Gullah occurs with the $/ v /$ sound, which is commonly replaced with the $/ \mathrm{b} /$ sound. Throughout Porgy, $/ \mathrm{b} /$ replaces the $/ \mathrm{v} /$ sound with words like "very," "starvation," and "never" written as "berry" (36), "starbation" (99), and "nebber" (123), and "give" and "living" written as "gib" (195) and libbin"" (184). The latter example also shows Heyward's use of the apostrophe to indicate the missing final letter "g." and to show that instead of the final "ng" or [0] $]^{21}$ sound, the $/ \mathrm{n} /$ sound is the intended pronunciation. Substitutions are also apparent in the following words: "fuhebber" for "forever" (33), "grabe-yahd" for "graveyard" $(27,32)$, and "ebery" for "every" (27).

\footnotetext{
${ }^{20}$ Jane Screven Heyward's papers, including seven "Gullah Notebooks" of collected stories, folklore, history, and anecdotes used in her published work and "dialect readings," are part of the Heyward Collection at the South Carolina Historical Society and are fully referenced in the Bibliography.

${ }^{21}$ The symbols placed inside brackets throughout the paper are from the International Phonetic Alphabet (IPA). IPA symbols are used by linguists to designate specific sounds. They are not bound by the orthographic symbols of a particular language and provide a far more accurate representation of human speech.
} 
Another example is the "th" sound, or more accurately, the various sounds represented by the letters "th" in written English - the phonemes [ $\theta]$ and [ð] - which are relatively rare in languages other than English. Gullah speakers commonly substitute the

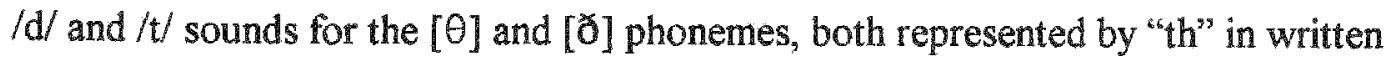
English. Accordingly, Heyward consistently writes "dis," "dat," "dem," "dese," and "dose," for "this," "that," "them," "these," and "those." Similarly, he depicts words like "brother," "father," "mother," and "whether," as "brudder," "fadder," "mudder," and "wedder," using the double consonant or "flap" [r] to replace the "th" sound and accurately represent the sound substitution made in the Gullah pronunciation of the words.

Frequently, the Gullah speaker will simply drop or ignore the problematic consonant cluster, such as the "th" $[\theta / \partial]$ sound in "them." Heyward sometimes depicts this by writing "um" (56), which he also uses for the Gullah pronunciation of the singular third person objective case pronoun "him" (73). Alternately, in words like "three," "through," and "throw," the Gullah speaker replaces the problematic "th" sound with the /t/ sound. Heyward writes these words as " $t$ 'ree," "t'rough," and "t'row," using the apostrophe to indicate his removal of the letter " $h$," which helps readers identify the words, but also serves to key the pronunciation and show that it is not that of Standard American English.

In her 1964 dissertation "The Representation of Gullah-Influenced Speech in Twentieth Century South Carolina Prose: 1922-1930,"Ann Sullivan Haskell points out that one of the difficulties in representing spoken Gullah lies in the fact that Gullah 
contains sounds that "are relatively rare in general American speech" (Haskell 20). She also notes that when Gullah speakers "substitute one commonly-encountered vowel phoneme (sound) of Standard American English for another, the graphic representative for the former may simply be substituted for the latter to produce easy recognition of this sound by non-speakers of the dialect being portrayed" (20).

Haskell gives the example of the English word "can." If the speaker being represented pronounces the word with a short "i" sound as in "pin," a writer can write "kin" to tell readers how the word is being pronounced. The context of the sentence will cue the reader to the fact that although the word is to be pronounced as "kin," it is to be understood as "can." Heyward uses this spelling - "kin" - for the word "can" throughout Porgy. Other examples in Porgy include the /a/ sound [e] in words like "make" and "take" This "long a" sound, which is not common in Gullah, is consistently represented by the /e/ sound $[\varepsilon]$, with the words written as "mek" and "tek" throughout Porgy.

However, when the substituted sound does not exist, or is not easily represented using standard graphic symbols (letters), it is difficult, if not impossible, to accurately depict it.

Other ways in which Heyward shows the linguistic variations that exist in Gullah phonology include the use of the letter "w" where standard English would require the letter "v" and the /v/ sound. He writes the word "advantage" as "adwantage" (56), and "Savannah" as "Sawannuh" (195), although he has primarily represented the pronunciation of the $/ v /$ sound using the letter "b." The actual sound Heyward is attempting to represent is called the "voiced frictionless continuant" [v] (Turner 241) and it is a sound not found in Standard American English and for which there is no letter or 
as both "atter" and "attuh"(44) in successive paragraphs. Examination of the early typed manuscripts show that the former spelling - "atter" was initially used in both paragraphs (Pm-04, 26). In a later manuscript, the word is written as "atter" in the first paragraph and "attuh" in the second (Pm-05, 29). It is possible that Heyward's different orthographic versions were intended to show linguistic variations between speakers, but there is no way of knowing definitively.

Linguists studying languages and dialects delineate numerous linguistic varieties within a broad category such as the Gullah language, or Southern American English. Factors such as the speaker's age and history, geographic location, the attributes of the surrounding speech community, the intended audience, the presence or absence of nonmembers of the speaker's speech community, and other factors of the particular situation relative to the specific utterance, such as the speaker's feelings toward the listener or listeners, all contribute to the variety of the language or dialect that is spoken.

Both Janie and DuBose Heyward were sophisticated enough in their knowledge of the Gullah language to recognize that there were different varieties of the language relative to different speech communities. In her stories, Janie makes repeated reference to the "old-time negro" as speaking with a deeper dialect - what linguists would refer to as the "basilect." Besides the historic time period and/or the age of the speaker, she is also cognizant of the significance of locale and the influence of white speech on the variety of Gullah spoken, and thus, she cites these as differences in linguistic variations.

In a piece entitled "Prelude" (JH-GN5), Janie discusses Gullah's linguistic and historic roots in Angola and the presence of African, or Angolan, words in Gullah. She writes: "Many of the Gullah words have still survived, and it is necessary that I use them 
in my program in order to be accurate. They belong in the speech of the old-time Negro, and in that of some of the new-time ones, who have lived far from the cities" (JH-GN5). In the Foreword to Brown Jackets, she writes: "The dialect varies slightly in several of these sketches. This is a characteristic that the native Carolinian will recognize, that of the urban Negro being more easily understood than the thick 'Gullah' of the rural black" (J. Heyward, Brown Jackets).

Certainly DuBose Heyward was aware of these linguistic variations. He shows considerable variation in his Gullah dialogue. However, due to the onus of presenting the Gullah dialogue of Porgy to non-Gullah speakers, Heyward's dialectal distinctions among the Gullah characters are minimal and difficult to discern. In addition, there is little background information given for the Gullah characters, which complicates the task of determining if the dialect representations for different characters differ, and whether any differences are intentional.

\section{Lexicon}

The vocabulary of a creole language - its lexicon - generally consists largely of words from the language of the dominant culture in which the speaking subjects find themselves. When linguists seek to identify the linguistic roots of a creole language, they search for "survivalisms" or words that do not come from the lexicon or vocabulary of the "lexifier," the language on which the creole is based (English, in the case of Gullah). These words have survived from one or more of the native languages of the original 
speakers of the jargon or pidgin that led to the creole language. ${ }^{22}$ Generally, some words from the original speakers' native tongues are found in all creole languages, but the amount varies widely.

The number of words from the speakers' native languages that are found in the creole language is determined by many factors including the existence of similar words in the dominant language (Holm 1988, 82). The ease of pronunciation of a word or words in the dominant language, and the uniformity of the word or words from the various native tongues that contribute to the creole are also factors. For example, in the African languages, Ewe, Ibo, and Woloff, the verb "to be" can be expressed with the word "de" [de] (Tumer 213-214). However, the verb "to be" in the language of the dominant culture (American English), has numerous forms (am, are, was, were). Thus, it is not surprising that in Gullah, the word "de" [de] is often found in place of the English verb form for "to be," or alongside it as an auxiliary verb.

Gullah contains, or retains, a number of words of African origin that have been adopted into the general lexicon of English, including: sack (the noun meaning "a bag,"), "tote" (the verb "to carry"), "yam" (the noun for "a starchy, tuber vegetable," relative of the sweet potato), "samba" (a verb meaning "to dance"), and "voodoo" (a noun meaning "witchcraft" or "sorcery"), a word derived from the African language Fon, although variations exist in other West African languages (Turner 190-208).

\footnotetext{
22 A croole language emerges from the need to communicate by persons within a group or community who do not share one common language. However, the creole being created may borrow more heavily from one or more of the native languages of the group members if some speakers share a language or there are linguistic similarities between two or more of the speakers" native languages. For more information on the formation of pidgins and creoles, see Holm.
} 
Heyward makes a number of lexical choices that serve to add authenticity to the dialogue of his Gullah characters in Porgy. He uses "tote" (122, 134), a fairly common word in the American South, and one identified as an African survivalism (Turner 203). He also uses the word "buckra," a creole word meaning a white person $(71,76)$. Heyward replaces the expression "fond of" in an early typed manuscript (Pm-04, 47) with the more idiomatic "lubbin' of" ("loving of") (Pm-05, 54) in the dialogue: "Yuh is goin" to be mighty lubbin" of dis goat attuh a while, Boss" (72). Similarly, "feemale" (sic) (Pm-04, 44) in the early manuscript, becomes "shemale" (Pm-05, 50). Heyward"s changes clearly contribute to the air of credibility created by his representation of Gullah.

Linguist John Holm points out that some "common lexical items have their origins in phonological or syntactic features peculiar to the creoles" (Holm 1991, 244). He gives the example of the idiomatic "What make..?" or "What makes...?" used for "Why?" in Gullah, and the declarative counterpart "That's what makes..." The idiom mirrors a similar idiom in the West African languages of Ibo and Yoruba, which translates literally as "What it makes?" (Holm 1991, 244). Heyward uses this Gullah idiom correctly in Porgy, in the question form "What mek...?" as in "What mek yuh don't tell...?" (94) and "What mek yuh ain't lay...?" (99). His awareness and accurate use of this idiom is further evidence of his fluency in the language and his desire to strive for linguistic integrity.

\section{Morphology}

Perhaps the most colorful aspect of Gullah is its frequent use of "calques," or the use of word phrases for various parts of speech, where single words would be used in another language. Non-linguists may see calques as synonymous with idioms as calques 
use word phrases to convey unique meaning, generally where word-for-word translation will not serve. Adjectives, prepositions, and adverbs are often expressed by such phrases. Porgy includes many examples: "all two" $(17,184)$ is used for "both," "gunnels under" (134) refers to Jake's boat being "full," "wall-eyed" (64) seems to mean "ugly," "sof wo'd" (soft word) (64) implies a compliment, while "sof"-headed" indicates a lack of intelligence. Interesting idioms are found in the following: "...I gots a ready hand wid bundle" (115) and "wid er Joseph coat on he back" (56). The first can perhaps best be translated as "I can help," and the second uses a Biblical reference - Joseph's coat of many colors - to describe the flashy dress of New Yorkers. Perhaps the most distinctive idiomatic expression in Porgy is "shemale sense" (65) which seems to refer to women's intuition. In his representation of the Gullah calques, Heyward further signals his linguistic familiarity with Gullah.

One of the more interesting morphological features of Gullah and other creoles is the way in which unique word combinations take on new meanings, often changing in syntactic function from the words' original usage in the "lexifier," or the language on which the creole is based (in the case of Gullah, Standard American English). Heyward gives us "cure up," a phrasal verb meaning "to get well," in this example from Porgy: "Yuh wants dat "oman cure up, ain't yuh?" (100). In Gullah, the expression, "to sweetmout," pairs the adjective "sweet" with the noun "mout" to create the phrasal verb "sweet-mout," meaning "to compliment." A variation of this phrase appears in Porgy's dialogue, as "...talk sweet-mout" 'bout" (64). Their ease-of-understandability by a nonGullah audience surely influenced Heyward's use of these common Gullah idioms. 
Although English present tense regular verbs are inflected to show morphological features such as person, number, and case, the Gullah verb employs these morphological distinctions with the base form of the verb. Thus, Gullah verbs are fairly straightforward - usually the present, first person singular form is used - and the precise "morphology" or meaning must come from the context or other discursive evidence within the sentence or in the surrounding sentences. The Gullah sentence "Saturday he go," if spoken or written in isolation, does not provide enough information for the receiver of the message to determine the intended tense - past or future. More information, from the context, or other discursive clues, is needed.

Gullah traditionally uses "pre-verbal" or "anterior markers" in the form of auxiliary verbs, to mark the verb for tense and aspect. Heyward shows considerable variation in his use of verb forms in the Gullah dialogue of Porgy, but it is not clear if these are linguistic variations or signs of decreolization ${ }^{23}$ One of the most obvious examples is the use of "been" [bin] as an anterior marker in front of the uninflected Gullah verb to indicate a past within a past situation. The Gullah dialogue in Porgy contains numerous examples, including: "been know" as in "But it can't be dat attuh knowing buckra long as yuh been know um, yuh ain't onduhstan' um any better dan tuh tink dey would dribe away po' cripple in de heat" (71). Another example is "been separate" as in "So fuh a long time now I been separate dem wid a divorce wut I mek up fuh de pu'pose" (73).

\footnotetext{
${ }^{23}$ Decreolization is the process of the language breaking down wherein it comes to resemble the "lexifier" or language on which it is based (in the case of Gullah, the lexifier is English). For deeper discussions of language death and decreolization, and the debate concerning the current status of Gullah, see Holm, JonesJackson, and Murwene.
} 
Another example is the use of the auxiliary verb or pre-verbal marker "done. One example from Porgy includes "done see," used where standard English would use "Saw," as in the following exchange: "Who did it, then!' snapped the man. 'Crown, Boss. I done see him do um,' Peter cried in utter panic" (35). Traditionally, Gullah would use only the base form of the verb as in "I see him do um" and the concept of the action being in the past would come from context. Yet, due to linguistic variation, decreolization, or some other reason, Heyward has used the pre-verbal marker. "Done" can also be used to indicate the present perfect as in "done sen"" for "has sent," as seen in this passage: "My Gawd!" exclaimed Maria, who was standing near. "Crown done sen' he buzzud back fuh bring trouble. Knock um off, Porgy. Fer Gawd' sake, knock um off befo' he settle!" (186).

Heyward's awareness of these syntactical constructs in Gullah is seen in the manuscript changes he made. In an early, typed carbon copy manuscript version, Heyward wrote "... she been wid Crown" (Pm-04, 88). In a typed manuscript that appears to have been made after the carbon copy, the text has been changed to read "... she done been wid Crown" (Pm-05, 98). The full sentence reads: "I gots er feelin" w'en Porgy 'oman come out de wood on de picnic, she done been wid Crown" (Pm-05, 98). The passage's context indicates that the pre-verbal marker "done" is being used much as the past perfect construction "had been" would be used in standard English.

In some examples, both aspect and tense are indicated by contextual clues and the presence of a pre-verbal marker, as in the sentence from Porgy: "Gawd done sen' he rain already fuh wash he feet-steps offen dis eart" (33). The presence of the word "already" is a contextual clue indicating past tense, and the pre-verbal marker "done" indicates the 
perfect aspect. Some linguists would see the apparent redundancy in this sentence as evidence of the evolutionary process of a creole language, specifically the decreolization process, in which pre-verbal markers often begin to appear as auxiliaries to uninflected verbs.

Gullah verbs are also not marked for aspect, or the expression of an action's completeness or incompleteness. As with tense, aspect is indicated either by contextual cues or the use of the pre-verbal or anterior marker - generally the word "done." In Porgy there are numerous examples of "done" preceding the verb to indicate completion or perfection, such as "...til he done dead" (98), meaning "until he has finished dying," "...dey done gots um lock up" (43) indicating a present and continuing action, and "...till dey done dead" (74), which refers to an incomplete and future action. In some cases, such as the past participle verb form, no auxiliary verb or pre-verbal marker is used and the only way to distinguish between the past participle or the simple past tense is by the context, and that method does not always provide a precise meaning.

In Porgy, Heyward correctly portrays this occasional ambiguity of meaning with the phrase "... he go fine..." (73). "So fuh a long time now I been separate dem wid a divorce wut I mek up fuh de pu'pose. An' he go fine, Boss" (73). From the context it is evident that the all-purpose Gullah pronoun "he" is referring to an inanimate object or concept: either the divorce decree itself, or the situation or process of using the decree to grant divorces. However, the intended meaning could be "it went fine," "it has been fine," or "it has been going fine." The sentence context does not provide enough information for a precise determination of meaning. 
For the most part, Gullah uses the base form of regular verbs and there is virtually no distinction between singular and plural forms. Number may be indicated by the presence of a qualifying pronoun such as "them" to show plurality. The phrase "Dem Septembuh storm" from Porgy (133) illustrates this method. A numeric adjective may be added for precise expression of number, as in "fifteen dollar" (27). Two notable exceptions are "mens," and "chillren" or "chillen," the Gullah plural forms for "men" and "children." In the Gullah dialogue in Porgy, in such sentences as "An' dem chillen ob mine, dem is raise wid ways" (emphasis in the original, 17) and "Yo' mens bes' go slow" (19), Heyward shows his knowledge of both the regular form for Gullah singular and plural nouns and the two irregular forms.

Gullah also uses the base form of nouns to indicate gender and when possession is being expressed. It is common for the words "man" or "woman" - or variations of them, such as "boy" or "girl" - to be attached to nouns when the speaker wishes to indicate gender, as in "girl child." An example from Porgy is the expression "she-gawd" (63) whose meaning seems to parallel the word "goddess." Possession is shown by association or word order; the example from Porgy of "Porgy "oman" (125), meaning "Porgy's woman," illustrates this. Gullah pronouns do not show distinctions of gender or possession, and they often do not reflect case distinctions.

Gullah pronoun use centers on the all-purpose non-gendered pronoun in both the nominative and objective case, and uses nominative case pronominal forms as determiners to show possession. The most obvious example of non-gendered pronoun use in Gullah is the use of the pronoun "he" generically, where "he," "she," or "it" would occur in standard English. Heyward's awareness of this characteristic of Gullah is 
evident throughout Porgy. In the passage where the Gullah lawyer Simon Frazier talks about the illegal divorce decree he has drawn up and has been issuing to his black clients. Speaking of the process, and the divorce decree itself, Frazier says, "An' he go fine, Boss" (Pm-05, 55) and "He seem tuh work berry well, too..." (Pm-05, 56). Evidence that the pronoun "he" in these lines is being used in place of "it" lies in the early Porgo manuscript. Heyward has the white, non-Gullah lawyer, Archedale, respond to Frazier saying, "I suppose that you have made a good deal of money out of it?" (Pm-04, 49). His use of the non-gendered pronoun "it" in this line makes it clear that the meaning of the pronoun "he" in the preceding lines of Gullah dialogue is intended to be the same as "it." Though the line spoken by Archdale quoted here does not appear in the final text, its presence in the early manuscript clearly shows Heyward's knowledge of Gullah's use of "he" as a non-gendered, all purpose pronoun.

The use of pronoun case distinctions is limited in Gullah. The nominative case depicted by Heyward with "I," "we," "yuh," "he," and "dey" - is used almost exclusively, including when standard English would require the objective or possessive case.

Examples from Porgy are numerous, but a few of the more memorable ones include: "...le's we go down" (165), "...gots he eye on" (55), and "...fix um so he own mammy..." (95). The possessive case does not exist in Gullah, and Heyward accurately reflects this by omitting it in the Gullah dialogue of Porgy. He does, however, make limited use of the objective case.

In Porgy, Heyward depicts the objective case through his use of "um" as the objective case pronoun for both the singular third person "him" or "her," and the plural third person "them" throughout Porgy. Yet, Heyward also represents the word "them" 
with "dem." And when the character Bess speaks of Maria, saying, "Yuh done hear um call me 'Sister,' ain't yuh?" (96), the "um" is being used where the standard English pronoun "her" would appear. In the next line, Heyward has Bess say, "Dat mean me and she is friend" (96), mixing the objective and nominative case in one construction.

In another example from Porgy - "Win' be in de eas' by tuhmorruh. It gots dat wet tas' ter um now" (137) - Heyward uses the non-gendered third person pronouns "it" and "um" in the same sentence, with both forms referring to the wind, and used where standard English would call for the non-gendered, singular third person pronoun "it." Sometimes in Porgy's Gullah dialogue, the objective case is used where the nominative case would appear in standard English, as in "Us ain't talk much..." (165). Looking at the early "Porgo" manuscript reveals that Heyward originally wrote: "We ain"t talk much..." (Pm-04, 105). Clearly, Heyward chose to use the less standard construction. What is less clear is the reason behind such choices. Since the choices do not aid understanding, and in some cases, they may actually complicate linguistic accessibility by a non-Gullah audience, it can be presumed that they were made for the purpose of linguistic accuracy, to present a better representation of the Gullah language as it was in the early Twentieth Century. ${ }^{24}$

\section{Syntax}

It is in the area of syntax that Heyward was forced to make the most concessions. He had to settle for an approximation of Gullah syntactical features to keep the dialogue

\footnotetext{
${ }^{24}$ Determining the accuracy of Heyward's representation of Gullah as it was spoken in Charleston in the early $20^{\text {th }}$ Century is a task for linguists. It would require comparisons with audio field recordings made in the area at the time, and even then, many factors relative to the interview and recording process would have to be considered when making conclusions about the language.
} 
of the Gullah characters intelligible to his readers. Thus, sentence structure and word order is largely that of standard English.

Gullah makes no distinction in voice, and the active and passive voices are used interchangeably with no change in meaning. Tumer found this to be a common feature of many West African languages, where the sentences "He was beaten" and "They beat him" would be expressed the same way (Tumer 209). This feature of Gullah is largely missing in the Gullah dialogue of Porgy however. As Gullah is only used in the direct discourse between characters in the novel - and not in any of the descriptive narrative passages - there are fewer instances where the passive could be expected to occur and this may explain the absence of this otherwise common feature of Gullah. It is also possible that the choice to use the active voice was a narrative technique employed by Heyward, the writer.

The frequent use of verb phrases or auxiliary verbs is a syntactic feature of Gullah that is seen throughout the Gullah dialogue in Porgy. In particular, the Gullah construction involving "for (spelled "fuh") + verb" for the infinitive form "to + verb" is prominent in the dialogue. Examples include: "fuh wash" (33), "fuh talk" (57), "fuh let" (166), and "fuh bring" (186). Gullah also has a verb "fa" and it is likely that Heyward mistakenly identified the word as a variation of the word "for." In one particular sentence, Heyward discriminates orthographically between what appears to be two different pronunciations of the word "for:" "Dat's all right now fer Robbins," commented Porgy. "Gawd done sen' he rain already fuh wash he feet-steps offen dis eart" (my emphasis, 33). While it is unlikely that Heyward recognized the Gullah verb "fa," the fact that he made orthographic distinctions indicates that he recognized a difference. 
Interesting syntactic constructs are evident in Gullah word order and Heyward includes a number of examples in Porgy. He uses the descriptive noun phrase "a "oman grown" (95) with the adjective following the noun, and there is frequent use of reflexive pronouns and repetition, though this is not an exclusively Gullah trait. As in standard English, the reflexive pronoun is used for emphasis, though a phrase like "Miss Rutledge sheself' (17) is Gullah in its lack of the possessive case. Heyward's knowledge, and depiction of some of the more obscure linguistic characteristics of Gullah is evident in the accurate portrayal of these constructions.

Heyward made careful and considered choices in representing the Gullah language as spoken by his Gullah characters in Porgy. Examination of the linguistic scholarship on Gullah provides the criteria to evaluate Heyward's representation and his firsthand knowledge of the language is evident. His concern for accuracy is apparent in the numerous revisions made to the Gullah dialogue. The linguistic detail and accuracy adds to the literary realism of the novel, and provides empirical evidence to identify the work as Gullah in its portrayal of the language. Identifying the work as being representational of Gullah linguistically is a major part of situating the text within a Gullah literary context and the larger sphere of African American Literary Realism. 
The people and events that shaped DuBose Heyward's life all contributed to his artistic success in the creation of Porgy, a novel of literary realism that would ultimately focus the world's attention on the Gullah culture in the South and help break down racial barriers in the theatrical world. Heyward had direct knowledge of the Gullah people and culture from his earliest days. These exotic, yet familiar, "others," who were always present on the periphery of his life, excited his artistic imagination. He observed and studied them, listening to their speech, their stories, and their methods of discourse, and noting the details with a writer's curiousity. He drew on real-life accounts of individuals within the Gullah community and he used his mother's first hand knowledge and her collected stories of Gullah history, daily life, customs and beliefs, as source material for his work. As a white, Southern male with a good name, he had access to the publishing world and hence, the national marketplace. This combination of interest, experience, and access served as the tinder; Samuel Smalls' arrest, and the murder of an unnamed black man, sparked the flame; and Heyward, the artist, fueled the creative fire that forged Porgy.

Heyward rejected the white Southern literary tradition of plantation stories, or Civil War romances and apologias, in favor of what he called "the bitter realism of the present" (IT, 1). He combined knowledge and research with a concern for accuracy and an intense desire for realism, and produced a serious work about African American individuals and their community. With Porgy, Heyward would give voice to the Gullah community and provide readers a glimpse into their world in the segregated South. In its 
connections to the tradition of African American Literary Realism, and its anticipation of the themes that would become the comerstones of the Harlem Renaissance, Porgy was something new in Southern Literature.

A cursory look at Heyward's biography might lead one to question his knowledge of, and connection to, Gullah language, locale, customs, culture, and beliefs in turn-ofthe-century Charleston, and thus, the accuracy of his portrayal of the Gullah people in Porgy. He was the scion of two leading South Carolina plantation families, both of whom owned slaves and land, in large amounts. His family was part of the white Southern aristocracy, with a paternal relative, Thomas S. Heyward, present at the signing of the Declaration of Independence. While Heyward did not complete high school (Hutchisson 12), he was a well-read and cultured gentleman, welcome in the drawing rooms and parlors of Charleston's elite society.

However, in-depth research into Heyward's background, experiences, and his acknowledged influences challenges the superficial portrait of Heyward as Southern aristocrat. Both his father's and his mother's families lost their wealth in the Civil War. His mother, Janie's ancestral plantation home was destroyed by fire (JH-GN3). His father died in a tragic accident when Heyward was only three years old (Hutchisson 6). As a young widow with two small children, Janie was left with little more than her good name. Heyward grew up in genteel poverty in downtown Charleston, side by side with the city's Gullah residents. He may have been an outsider to their world, but he was no stranger.

Growing up, Heyward spent a lot of time in the Gullah neighborhoods and environs. As a boy, he had a job with an insurance company collecting the twenty-five 
cent payments toward burial insurance in the Gullah quarters (Hutchisson 9). The Gullahs paid, in part, because of the superstition that not paying invited death. In his free time, he swam off of the wharves where the black stevedores worked. In his teenage years, he worked on his aunt's plantation in the summer, supervising the black field hands. In order to help support his family, he held a variety of jobs as a young man. He was employed as a cotton checker on the same docks he'd played on as a child. He went door to door in the black neighborhoods, selling war bonds, and later, burial insurance, before starting an insurance business with a childhood friend as partner. He dabbled in real estate and renovated some of the city's black tenements (Hutchisson 9-10). Clearly, Heyward was not unfamiliar with the Gullah people, observing them only from a distance; he lived and worked in close proximity to them and like his mother, his knowledge was first hand.

A primary source of direct knowledge of Gullah history, language, and culture, for Heyward was his mother, Jane Screven (DuBose) Heyward. Janie, as she was known, was born to a slaveholding family and raised by Maum Sinai, her beloved Gullah "Mauma." She understood and spoke Gullah with fluency. In a story called "Gullah in the Wrong Place" (JH-GN1) from her readings, Janie tells the story of the young daughter of a plantation family who spends her days speaking Gullah. One day, the girl's mother warns her not to speak "like a little negro" (JH-GN1) when the bishop comes to dinner. The little girl tries, but in her excitement she lapses into Gullah, much to her mother's embarrassment. It would seem likely that the little girl of the story is Jane herself. In her Gullah stories, she sometimes does not refer to herself directly, calling 
herself Jane or taking on the role of observer, as in this story. If not completely autobiographical, it is likely that the story mirrors Janie's own childhood experiences.

The accuracy of Janie's Gullah "dialect," as heard in her recitals, is mentioned repeatedly in the collected newspaper reviews and quotes, found in her collected papers. ${ }^{25}$ One article, dated March 26, 1925, states: "She knows her subject well, she has the gullah (sic) language perfected to a remarkable degree, and with this she has the accent. ${ }^{26}$ Janie's influence on DuBose cannot be overestimated. She was a Gullah enthusiast, collecting Gullah stories and anecdotes as well as writing down her own recollections and creating poems using the Gullah vernacular. In addition to filling some seven notebooks ${ }^{27}$ with her Gullah material, Janie sold material to a well-known dialect recitalist before eventually developing programs of her own (Hutchisson 8). She also had three privately published books of poetry, and "before the war" or "plantation tales" between 1905 and 1921, most of her work either in Gullah or incorporating it in the dialogue." In 1923, the State Company of Colombia, South Carolina published Brown Jackets, a book of "sketches of the Gullah Negro" (J. Heyward, Foreword. Brown Jackets).

\footnotetext{
25 Jane Screven Heyward's collected papers are part of the Heyward Collection at the South Carolina Historical Society in Charleston, reference $\# 1172.03 .01 .01-14$, and -15 .

26 The article is entitled "Dialect Program Delights Group" and dated 3/26/25, but there is no indication of the name of the newspaper or author. It can be found in her collected papers as part of the Heyward Collection at the South Carolina Historical Society, in Charleston, reference $1172.03 .01 .01-15$.

${ }^{27}$ Jane Screven Heyward's "Gullah Notebooks" 1 1- 7 are part of her collected papers and are found in the Heyward Collection at the South Carolina Historical Society in Charleston. They are fully referenced in the Bibliography,

${ }^{28}$ A collection of articles and reviews of the dialect recitals or readings given by Jane Screven Heyward, and her published work, are found in her collected papers in the Heyward Collection at the South Carolina Historical Society in Charleston, reference $\$ 1172.03 .01 .01-14,-15$, and -23 .
} 
Janie studied the language, reading the writing of others in Gullah and practicing her speaking. She dedicated her book Brown Jackets "To Ambrose E. Gonzales, 'The Pathfinder"' and in the Foreword, she acknowledges him for making "the Gullah dialect accessible for the purposes of literature" (J.Heyward, Brown Jackets). In the piece "Him Dead?" from her notebooks, Janie recounts practicing her Gullah by telling her stories to "Maria, my Sea Island exponent of that language" (JH-GN4). After Janie tells a story, she receives Maria's positive verdict: "I declare Miss Heyward, You is too sma'at, "E mek me die wid deh laugh foh yeddy you deh talk, like dem OLD time colored people" (JH-GN4), Janie went on to become one of the most successful dialect recitalists of her day (Hutchisson 8), giving readings at churches, garden clubs, and ladies' drawing rooms throughout the South. Clearly, her son had a rich source of material to mine for his work. Like many a white Southerner raised before "the War," Janie felt a close bond to the Gullah people whose presence dominated her youthful world. Throughout her life, she associated the Gullah people and their culture with the warmth and communal spirit that she had come to know as a child. Her notebooks contain numerous poems and stories that describe her deep affection for specific individuals, and the Gullah people and culture as a whole.

As an adult living in Charleston after the War, Janie's connections to the Gullah people continued and her son, DuBose came to know the Gullah people from Janie's youth. In her writings, ${ }^{29}$ Janie tells the story of her Charleston wedding. On her wedding

\footnotetext{
29 This story appears in the "Introduction to Third Program" from Gullah Notebook 44 found in the Heyward Collection at the South Carolina Historical Society in Charleston. The notebooks are fully referenced in the Bibliography.
} 
day, an unexpected contingent of the old family servants from the country arrived with a variety of live animals in tow, intended as gifts for the wedding feast. They were there "to come ter Missy "weddin"" (JH-GN4) and the family had to scramble to accommodate them. Janie expressed her happiness at seeing them, writing: "And that night as I walked up the aisle of Old St. Philip's church in Charleston, and looking upward to the gallery, saw the group of familiar, kindly, eager Brown faces. I was glad that they were there" (JH-GN4). In the 1927 article "Porgy of Catfish Row" DuBose Heyward recounts the many Gullah visitors with connections to his family "who used to make pilgrimages from the country to see us" (TGQ, 8). He says he was "always a countryman at heart" and would "sit and talk to them by the hour, and listen to their stories that were always full of color and laughter" (TGQ, 8). Like his mother, Heyward found much to admire in the spirit of the Gullah people.

It is possible to find direct sources within Janie's material for many of the elements and scenes in Porgy. For instance, the name of Heyward's protagonist, and the title of the novel in the first typed manuscript was "Porgo." "Porgo" was the name of an African doll that belonged to Chloe, a slave girl taken from Africa as a child and purchased as a companion for the young Janie. Janie writes of it in her story called "Porgo" in her Gullah Notebook \#3. In a poem entitled "Street Cries," she records the cry of the Gullah fish peddler and his calls of "Pawgie - Pawgie - Ten cent a string" to sell his catch of fresh porgies (JH-GN1). In the early typed manuscript version of Porgy, Heyward describes fishermen selling strings of freshly-caught "whiting and porgy" (Pm04, 24). In some typed manuscript fragments, he has crossed out "porgy" and written in "crokers" (sic) (Pm-02, 20). In the carbon copy manuscript (Pm-04, 28) and the text 
Porgy (42), the phrase appears as the original "whiting and porgy." Though the inspiration for the name "Porgo" may have come from Janie's story, Heyward seems to have preferred to let readers make the connection to porgy, a common type of fish.

Some scenes in Porgy may have been modeled in part on real dialogue and scenes from Janie's writings. The courtyard scene in Porgy where the Gullah residents pretend they don't understand Archdale, the white lawyer, when he comes looking for Porgy is one example:

"'Oh, yuh means Porgy?' she cried, as though she had just heard the name for the first time; 'I ain't understan' wut name yuh say, Boss,' and echoes arose from different parts of the court. 'Oh, yes, de gentleman mean Porgy. How come we ain't understan'" (59, emphasis in the original).

In Janie's Notebook \#5, a piece called "Town" features similar dialogue: "Oh, no Missie' he answered, 'I ain' know you talk Sabanna, Enty yoh say 'Town'. I is t'ink yoh mean Chal'son." Heyward's scene in Porgy resembles the one in Janie's story; both depict Gullah speakers offering seemingly sincere apologies and pretending confusion was to blame for their initial failures to cooperate and provide the requested information.

This duplicitous reticence followed by feigned misunderstanding is a subversive behavior called "masking" and it is a component of the rhetorical tradition known as "signifying." Noted scholar and critic Henry Louis Gates, Jr. in his 1988 landmark text The Signifying Monkey: A Theory of African American Literary Criticism, says that while "signifyin(g) (sic) is not the exclusive province of black people" (90), they named it and "invented its rituals" (90). Signifying is strongly associated with the black vernacular and takes different forms, depending on the parties involved in the discourse. Perhaps the 
most common example of signifying within the black speech community is in the reclaiming of the term "nigger" and its transposition from racist slur to a term indicating insider status. The Gullah characters in Porgy use the term frequently among themselves - with both positive and negative connotations.

Another form of signifying is known as "playin" the dozens," or exchanging mock-insults in a competitive and verbally combative back-and-forth that escalates in scale until one party can no longer top the preceding remark. Heyward may be incorporating a scaled down version of "playin' the dozens" in an interchange between Old Peter and Serena. It begins when Peter speaks complimentarily about Bess, alluding to her sexuality, knowing it will provoke the self-righteous Serena.

"...he emitted an indiscreet chuckle, which was too much for his friend.

'Yuh po', ole, wall-eyed, sof-headed gran'daddy ! Ain't yuh 'shame' tuh set dey befo' me, an' talk sweet-mout' 'bout dat murderin' Crown's Bess? Ef I wuz yo' age, an' er man', I'd sabe my sof' wo'd fer de Gawd-farin' ladies. "" "Ef yuh wuz my age, an' a man-" commenced Peter. He hesitated, and looked long at her with his dim, kindly eyes; then he shook his head. "No; it ain't no use. Yuh wouldn't onderstan"' (64).

After this interchange, the two part ways with no hard feelings, which is characteristic of the friendly-nature of the verbal game "playin" the dozens."

As a means of resistance and protection, signifying is commonly utilized in the form of masking with suspicious strangers, particularly whites. When the lawyer, Archdale initially enters Catfish Row, he reaches out to touch a young woman walking by him and "She stopped, and turned immediately toward him, her eyes lowered, her 
manner submissive, but utterly negative" (58). When he asks for Porgy, she repeats the name slowly, "as though trying to remember" $(58)$ and then calls out to the bystanders: "Anybody hyuh know a man by de name ob Porgy?" (58). Several of the listeners echo the name, "Porgy" and shake their heads. Evidently, Archdale has encountered this type of behavior before and understands it: "The white man laughed reassuringly, as though quite used to the proceeding. 'Come,' he urged, 'I am his friend, Mr. Alan Archdale; I know that he lives here, and I want to help him" (58). After he explains himself and is recognized by Serena, Porgy is sent for and the aforementioned scene occurs, wherein the young girl pretends she has not understood him.

Heyward recognized masking for what it was, and like his character, Archdale, he was no stranger to the behavior. Masking is seen again when Archdale confronts Porgy, who, at first, does not know who he is or why he has come. When Archdale asks Porgy about his friend Peter, Porgy is wary and silent. Archdale tries again, "'But, tell me about your friend,' said the visitor, breaking a silence that was becoming tense. Porgy's face still wore its mask" (60). After Archdale explains who he is, Porgy remains distrustful that this white lawyer has come to help Peter. "Peter ain't gots no money, yuh know, Boss. An' I jes begs from do' to do.' There was still a shade of suspicion in Porgy's voice" $(60)$. Only when he is completely satisfied that Archdale has been sent by the Rutledges and that they will pay any fee incurred, does Porgy determine that it is safe to drop the mask and answer Archdale's questions.

In addition to finding rhetorical models for portions of the dialogue in Porgy in his mother's stories, Heyward found inspiration for parts of the plot as well. In "A Change of Sentiment" from Janie's Notebook \#1, a Gullah woman seeks a divorce. 
When the judge questions her, she admits that her husband does not beat her and does bring home his wages to her. She explains: "He ain't done nuttin, judge. I lost my taste for um, t'ree mont' ago." In Porgy, the Gullah lawyer, Simon Frasier gets in trouble for creating illegal divorce decrees. When the white lawyer Archdale asks, "Don't you know there is no such thing as divorce in this state?" Frasier replies: "I hyuh tell dere ain't no such t'ing fuh de w'ite folks" (74). Frasier says he is performing a necessary service to keep his black clients happy. While Janie's story seems to emphasize the condescending idea that the blacks change partners on a whim, Heyward's version shows the reality of blacks and whites living in two separate worlds, and raises the idea that white laws don't fit black lives. Heyward may have turned to his mother's material for ideas but he wrote from his own experience.

In addition to the writings of his mother, Heyward found inspiration in real people, places, and events. Most significant is the model for his protagonist, Porgy, who was based on a real person. Samuel Smalls or "Goat Sammy," was a cripple who traveled the streets of downtown Charleston in his goat cart, just like Porgy. A short news piece from the Charleston News and Courier in 1921 is among Heyward's papers; it reports Smalls' arrest for attempting to shoot a woman named Maggie Bames, though his bullets missed their mark. It was the second such incident in recent months. In his typed notes for the Introduction to the play Porgy, Heyward says he was fascinated that this seemingly pathetic beggar, whom he passed every day, clearly led a life that included "passion, hate, despair" (PI, 2). Heyward acknowledges that this information made him question his assumptions about life "across the colour wall" (PI, 2), and he carried the news clipping in his wallet for a number of years. 
With a writer's natural curiosity, Heyward sought more information and found out details regarding Smalls that are directly reflected in Porgy's plot. He learned, for instance, that Smalls had tried to escape from the police in his goat cart and been run down and apprehended by the police patrol wagon. The power of this scene in Porgy lies in Heyward's narrative. Exercising a writer's perogative, Heyward fills in the missing details: "...as he came, he was greeted with shouts of laughter and witty sallies from the crowd. $[\ldots]$ it seemed that even the sedate officers of the law were not above a sly humor of their own, for the vehicle slackened its pace perceptibly and prolonged the final moment of capture" (191). Heyward recreates the imagined scene with a hard-edged realism that reflects his awareness of the way that the majority of the whites viewed the blacks. His description of the laughter and jeers of the white crowd in response to Porgy's (Small's) tortured desperation adds pathos to the scene.

In recreating Smalls' public anguish, Heyward brings to voice this unlikely protagonist, while focusing a lens on Charleston's citizens and officers of the law. In the introduction to the play Porgy, Heyward writes: "The obscure beggar with his malodorous goat bids fair to become a local legend" (PI, 54). Heyward writes Smalls into history beyond the narrow dimensions of the newspaper account and he invests Smalls' story with a deeper and more nuanced social context, one that includes both Smalls and the community.

By using the names of real Gullah people, Heyward creates realism and he gives voice to those whose stories would likely never enter the public sphere otherwise. The character of Peter was originally called Scipio in the early typed manuscript of Porgy. Examination of the manuscript shows the name "Scipio" crossed out with "Peter" and 
"Old Peter" written in by hand (Pm-04, 5). Scipio was the name of the Gullah slave who served as the coachman for Janie's family and was married off to the aforementioned Chloe, owner of the African doll, Porgo (JH-GN1). It is possible that the real Scipio served as a model for the character Peter. Heyward also used the name Scipio later, for one of the children in the play Porgy. The name of one of the respondents in a divorce case handled by the Gullah lawyer Simon Frasier is Rachel Smalls. Smalls is the last name of "Goat Sammy" or Samuel Smalls, the model for Porgy. Not only is Heyward writing these individuals into the public space, he is doing it on a national scale. What some might see as minor details - using the names of real Gullah people - are, in fact, symbolic of Heyward's intense desire for realism. Porgy may be Heyward's text, but it is their story.

Similarly, "Catfish Row," the setting for Porgy, is modeled on "Cabbage Row," an enclosed courtyard between two buildings located at $89-91$ Church Street in Charleston's old "Negro quarter." Heyward lived at 76 Church Street, diagonally across from the real "Cabbage Row," and he passed the Row every day as he walked to work. A number of newspaper articles found among Heyward's papers recount the sale of Cabbage Row in 1928 and provide detailed descriptions of the Row. From these, it is evident that Heyward's "Catfish Row" in Porgy is closely modeled after the real Cabbage Row. A 1928 New York Post article reports that Cabbage Row was the worst black tenement in town (NYP). As depicted in the novel, it was the first place the police came looking for suspects whenever a crime was committed.

Further evidence of Heyward's care in constructing the novel is found in his handwritten research notes and collected story ideas. These notes contain information 
about a woman named Bess, who was a drug addict, well known to the city's police department. She was a prostitute, "known to take on as many as forty" of the workers from the phosphate mines in a single afternoon, and she kept company with an older black man, "mild mannered and kindly" (RN). She was reported to have killed herself by drinking laudanum but not before saying: "Tell anybody who asks that Bess died for love of $\quad$ " (RN) and she mentioned a name those that knew her had never heard. Clearly, she was the model for Porgy's Bess in Heyward's novel. Other notes refer to a woman with a scarred face who gave candy to the children, something Porgy and Bess do in the novel. Though Bess appears to be a composite character, Heyward constructed her based on real women.

Heyward's experiences as a boy, provided the background for the "saucer burial" scene in Porgy. As a child, Heyward had a job collecting the monthly twenty-five cent payments for burial insurance from those in the black neighborhoods. When someone died without burial insurance and the family was too poor to pay, the body was laid out and a saucer was placed on it. The mourners gathered and held a kind of wake, singing and praying while people came and put what they could in the saucer. It was a source of great shame to the family to have a "saucer-buried" relative. In Porgy, Robbins" penniless widow is forced to hold a saucer burial.

Clear evidence of Heyward's knowledge of the traditions, religious practices, and culture of the Gullahs is apparent throughout Porgy. The call and response rhetorical pattern that is part of the African oral tradition is accurately depicted in Porgy. At the funeral, an elderly Gullah woman cries out, "Tell Peter tuh hold de do" open fuh me. I's comin' soon!" and a voice answers, "Yes, Gawd, goin' soon" (31). When Bess is sick, 
Porgy rejects Peter"s suggestion that he take her to the "w"ite folk" hospital and instead, embraces Serena's offer to pray over Bess. She prays, in a dramatic, sermon-like style and the gathered group acts as her respondents. They encourage and support her, echoing her words like a chorus. Serena prays for Jesus to cast out the "Debbil" that has possessed Bess, "...lak yuh use' tuh do, time an' time agin?", and the group responds, "Time an' time agin!" (100). Heyward's knowledge of the African American church and the rhetorical style of the sermon is evident.

Heyward was also quite knowledgeable about African American spirituals. In the 1930 's he became a founding member of a preservation society dedicated to recording and preserving the spirituals. In a letter to his friend John Bennett, dated May 13, 1924, Heyward wrote that he had almost finalized arrangements for his partner to buy him out of their insurance business partnership. He wrote: "In the words of the Negro spiritual 'My soul so happy til I can't sit down' "(JBL). A variation of this spiritual appears in Porgy; "Pain gots de body, an' I can't stan' still" (24). Heyward includes other spirituals in Porgy in his representations of communal grief at the wake and funeral, and shared fear during the hurricane.

In addition to knowing the words of the spirituals, Heyward is well versed in the musical idioms that constitute the form of the spirituals. He makes several references to "music in minor keys" (Hutchisson 51) and this is in keeping with the African tradition. Unlike music of Anglo-origin, African melodies are based on the Pentatonic or five-note scale, which turns on the note called "A," known as the "blue note" in English. "A" is a minor key and one of the primary keys used in the spirituals; hence, the references to "a heart-wrenching minor" (30) and "vague, uncertain minors" (31). It is interesting to note 
that Heyward refers to the call and response rhetorical pattern of the spirituals using classical Greek terms. He uses "strophe" for the call, and "antistrophe" for the response: "What de matter, chillen?' came the strophe. And the antistrophe swelled to the answer" $(23-24)$. While it is unlikely that Heyward understood the African origin for the unique form of the spirituals, his practical knowledge of them is clear.

Yet another aspect of Gullah culture in the late $19^{\text {th }}$ and early $20^{\text {th }}$ centuries that Heyward accurately presents in Porgy is the duality of their religious beliefs. They embraced Christianity while continuing to practice traditional African beliefs such as the belief in spirits, animism, and conjure or "root," with equal faith. Heyward presents this perfectly in the scene where Porgy is worrying about Bess' illness. It is agreed by all that Bess' fever and semi-comatose state is a form of possession, by the Devil or evil spirits. Serena, the Gullah woman whose family once belonged to the Governor, questions Porgy's faith in her Christian God and asks him why he has not asked her to pray over Bess. She reminds him of the past when she evidently prayed for him, and his problem was solved. Porgy acknowledges her point and eagerly accepts her offer. However, when Maria proposes that he send Mingo to one of the sea islands to the cabin of the conjure woman, Lody to purchase a "conjure" or spell, he embraces that idea with equal enthusiasm.

The strong presence of the Christian faith in the daily life of the Gullah people is seen throughout Porgy, in both the good times and the bad. In addition to the expected times and places such as the wake and the funeral, and the formal forms of communication such as prayers and singing, Porgy speaks to God spontaneously and without ceremony. In awe of something like the view of a huge steamer ship, "Gawd 
sho gots a long arm,' he would murmur; or, 'Porgy, yo' sho is a little somethin' aftuh all'" (49). When Bess comes out of her fever-induced trance, he calls out "T'ank Gawd!" (104) over and over. The Christian God is depicted as a powerful but benevolent master. The African religion referred to as "conjure" - written phonetically as "conjer" in Porgy and often called "root" in Gullah from its use of dried roots in spells, charms, and potions - exists side by side with Christianity in the hearts and minds of the Gullah people. It is associated with Maria, the older Gullah woman who runs the cookshack, who is depicted as being more African in her commanding physical presence, her proud demeanor, her wearing of the traditional headwrap, her wisdom, and her powerful belief in conjure. It is perhaps noteworthy that Heyward has Mingo fail to make it to the conjure woman. Thus, it appears that Bess' recovery is the work of Heyward's Christian God. When Maria hears that Bess is getting better, she discovers that Mingo never went and she locks him in her closet to insure that he is not seen. She does not want people's belief in conjure eroded. She speculates that God may have been responsible for Bess' recovery, saying, "Mus' hab been Jedus done um atter all.' Then, as though to dismiss the matter, she adds: "No, I be damn ef he did. He ain't gots it in um" (107). For Maria, the kind Christian God does not have the power that conjure possesses, and which is required to chase away evil spirits.

The Gullah belief in spirits is equally prominent in the daily lives of the people. Throughout Porgy, the buzzard is seen as an evil spirit and its presence is considered a bad omen or a sign of coming death. It is also believed that the dead may return in another form and when the buzzard lights on Porgy's roof near the novel's end, we are led to believe that Crown has come back to exact his revenge on Porgy for killing him. 
Subsequently, Porgy is jailed and he loses his beloved Bess. In the graveyard scene, the mourners run from the graveyard as soon as the service is over, due to the superstition that the last one out will be the next one to be buried. Similarly, Clara was told once by a conjure woman that her husband Jake would die by drowning and she is afraid every time he takes his boat out. The prediction proves true, as Jake is lost at sea in the hurricane. Janie was very superstitious and likely passed some of her beliefs to her son. Thus, it is not unusual that Heyward's portrayal of the Gullah beliefs in omens and spirits seems one of acceptance.

Animism, or the assigning of spirits to inanimate objects, is represented in the personification of such conceptual entities as Death, Luck, Sense, and even Starvation. The mourners in Porgy cry out to Death, "...Ain't yuh gots no shame?" (30). Similarly, Porgy points out that Sense - as in common - may do very well for himself but he can't "lift no weight" (43). Starvation is said to stand and "look yuh in de eye" (99). Luck is a horse that you can only ride so far before it runs out. Heyward's treatment of these instances is matter-of-fact and shows his acceptance of the Gullah beliefs, rather than skepticism.

One of the most dramatic scenes in Porgy is the Saturday night crap game that ends with the murder of Robbins by Crown and the strength of the scene is in the vivid details. Heyward's earlier poem "Gamester's All" lays the groundwork for this scene but it lacks the power of the scene in the novel. In order to explicate this point, it is necessary to quote at length:

"Porgy witch dem dice,' Crown snarled, as he drained his flask and sent it shattering against the pavement (18). [...] Then in a flash it 
happened. [...] With a low snarl, straight from his crouching position, Crown hurled his tremendous weight forward, shattering the lamp, and bowling Robbins over against the wall. Then they were up and facing each other. The oil from the broken lamp settled between two flags and blazed up ruddily. Crown was crouched for a second spring, with lips drawn from gleaming teeth. One hand touched the ground lightly, balancing the massive torso. The other arm held the cotton-hook forward, ready, like a prehensile claw. In comparison Robbins was pitifully slender and inadequate. There was a single moment of indecision; then he took his only chance. Like a thrown spear, he hurled his lithe body forward under the terrifying hook, and clinched. Down, down, down the centuries they slid" (19).

Heyward's intensely physical description may well include a trace of his own envy. Stricken with polio, typhoid fever, and pleurisy as a young man, Heyward had a permanently weakened arm and a thin, non-muscular frame (Hutchisson 11). He admired the powerfully built stevedores he saw frequently on the wharves.

In a letter to his friend and fellow poet Hervey Allen dated July 15, 1924, Heyward writes about the novel he is working on. "I have already, in the first three thousand words, a Negro crap game and murder that makes Limehouse Nights pale" (HAL). ${ }^{30}$ In the article "Porgy of Catfish Row" in 1927, he describes being a boy on the cotton wharves and watching "dim figures in a deserted warehouse comer squatting over

\footnotetext{
${ }^{30}$ Limehouse Nights is a collection of stories by Thomas Burke published in 1916. The stories are set in London's Chinatown and take the reader down into the seamy side of life.
} 
a crap game" (TGQ, 8). Living across the street from Cabbage Row, the model for Porgy's Catfish Row, and working on the cotton wharves, Heyward surely caught glimpses of the occasional liquor-induced brawl as well. His recreation of the players' taunts, supplications, and curses is distinctly realistic - "Oh, my Baby," "Come seben," and "Roll me a sun an' moon!" - and likely came from the real games he overheard.

Heyward felt strongly about a writer writing from his own experience. In a typed transcription of an interview with Selma Robinson of the Literary Guild, Heyward said: "The writer who would give his best will always turn to the subject that moves him most deeply, and so the Southern writer will set his story, naturally, where he himself belongs" (IT). In the introduction to the play Porgy, Heyward recounts witnessing a raciallymotivated killing of a fleeing black man, shot down in cold blood by a white police officer. Deeply affected by watching the man die, literally at his feet, Heyward took his vacation time and wrote the poem "Gamesters All." He says it was then that he knew he would one day be a writer and that his first work would be about the Gullah, the southern black (TGQ, 8). His vision and his conviction were clear and ten years later, he turned his experience into Porgy. 


\section{Conclusion:}

A close examination of DuBose Heyward's life and times reveals why Porgy sits squarely within the early 20 th Century literary traditions marked by African American Literary Realism and the more specific period of the Harlem Renaissance. Heyward was uniquely situated to become the writer to break the mold of the "old South" minstrel-style depictions of black life and to portray the Gullah people of his native Charleston with integrity and respect. In light of the integrity of Heyward's representation, Porgy deserves to be accorded its place in the Gullah literary tradition.

Recognition of the history - literary, linguistic, and social - of the Gullah culture is significant because development is threatening the Gullah. In recent years, there has been a renewed interest in Gullah culture and efforts are being made to insure its survival. In 2002, the South Carolina Bar Association and the Community Foundation Serving Coastal South Carolina created a program called The Heirs' Property Preservation Project. The Project aims to provide legal information and assistance to Gullah landholders and heirs who hold land as "Heir"s Property," or without title as a result of land grants and purchases by former slaves following emancipation. Without clear titles, individual heirs can sell property that may belong to multiple descendants of the original owners. With economic pressure, many heirs succumb to the temptation and land is sold without the knowledge of the other heirs, who have little legal recourse because they lack clear title. The project is funded in three South Carolina counties by a Ford Foundation grant of $\$ 150,000$ (Smith $22 \mathrm{~A}$ ).

In 2003, the National Park Service released a report of a three-year federal study conducted to determine ways to preserve the unique culture of the Gullah (Burch 1A). It 
found that development of the Sea Islands of South Carolina and Georgia was the primary threat to the Gullah way of life. These islands are the historic homeland of the Gullah people and where they lived in relative isolation until the 1950 's when bridges to the islands were built making access easier and opening the door to development. The study recommended establishing three Gullah cultural centers in South Carolina and Georgia, and creating a Gullah National Heritage Area. Congress has since reviewed the report and is considering funding the proposed cultural centers.

In May of 2004, the National Trust for Historic Preservation included the "Gullah-Geechee Coasts" on its 2004 list of America's 11 Most Endangered Historic Places" (Seabrook A1). It is an innovative step for the Trust to designate an undefined geographical area as opposed to a specific site, but it was deemed necessary to help alert the public to the imminent threat to the Gullah way of life.

It is impossible to know whether these efforts and the resulting attention drawn to the Gullah will help preserve a disappearing way of life, or hasten its demise. As the land is developed and its value goes up, taxes are raised and the pressure to sell increases. With the erosion of the geographic boundaries of the remaining Gullah communities, the number of speakers of Gullah dwindles and the language faces possible extinction. The creation of Gullah cultural centers administered by the National Park Service may tum out to be the death knell for the culture. One has only to envision the kind of commercial re-creations of "authentic" plantation life that exist throughout the South, with Gullah actors winnowing rice, weaving baskets, or performing the traditional religious practice of a ring shout for the amusement of tourists, to be concemed about where this type of federal intervention and attention might lead. 
Less tangible than land or handicrafts, the Gullah language and culture must also be preserved. With their ancestral African roots, the Gullah bear witness to the history of African Americans and are living reminders of the past, for good or ill. The Gullah language's African words and idiomatic expressions, its thetorical practices and patterns grounded in the African American oral tradition, are as distinct as the music of the spirituals, or the artistry in the sweetgrass baskets. It is the language of the slaves and the root of African American Black English. Gullah culture is the culture of Africa, precious metal smelted and forged, and surviving hundreds of years after its transplantation and recreation on new ground.

The study of the language and culture and the recognition of a Gullah literary tradition in works like Porgy, awakens us to the presence of a rich deposit of textual "gold" waiting to be mined by scholars. Unearthing a Gullah literary history enriches and informs the present in African American Literary and Cultural Studies, and moves us in the direction of expanding the definitions and parameters of African American Letters. In the language of empowerment: "you have to name it, to claim it." Identifying a classic American literary text - Porgy, and its famous progeny Porgy and Bess - as part of Gullah's literary heritage, is the first step. 
Andrews, William E. "The Representation of Slavery and the Rise of Afro-American Literary Realism, 1865-1920," African American Autobiography: A Collection of Critical Essays. Ed. Andrews, William L. (ed. \& introd.). Englewood Cliffs, NJ: Prentice Hall, 1993. pp. 77-89. Article traces the evolution of black narrative and realism from the antebellum slave narratives, to the post-bellum revisionist narrative associated with Washington and Tuskegee Realism, to the modern "fictive autobiographies" of Chesnutt and Johnson.

Bailey, Comelia with Christina Bledsoe. God, Dr. Buzzard, and The Bolito Man, a Saltwater Geechee Talks about Life on Sapelo Island. New York: Anchor Books, 2000. pp. 1-334. Bailey's contemporary memoir about growing up "Geechee" in the mid-Twentieth Century documents a way of life that is disappearing.

Bailey, Guy and Natalie Maynor, Patricia Cukor-Avila, Ed. The Emergence of Black English. Amsterdam: John Benjamins Publishing Co., 1991. Using a group of audio recordings of ex-slaves found in the Archive of Folk Song in the Library of Congress, the editors present transcriptions of the interviews followed by commentary and analyses by a historian, a museum curator and seven linguists. The essays examine the texts in terms of the roots and development of Black English.

Baker, Houston A. Jr. Blues, Ideology, and Afro-American Literature. Chicago: University of Chicago Press, 1984. Literary theorist, Baker connects the idiosyncrasy of the blues riff, with the railroad crossing as a site of discursive juncture, to formulate a uniquely African American literary theory.

Bennett, John. "Gullah: A Negro Patois." South Atlantic Quarterly. vol. 7 (1908) 332347 , and vol. 8 (1909) 39-52. Written at the turn of the $20^{\text {th }}$ Century by a native Ohioan, this article attempts to explain Gullah's origins as a remnant of old English with African and French creole influences. While many of the details are accurate, the underlying assumptions expressed about the Gullah people and the language derive from racist premises that were common at the time.

Conroy, Pat. The Water is Wide. Boston: Houghton Mifflin, 1972. This is the memoir of an idealistic young teacher who chose to live and teach the Geechee/Gullah children on the isolated Yamacraw Island off the Georgia coast in the late 1960's.

Cunningham, Irma Aloyce Ewing. A syntactic analysis of Sea Island Creole. Tuscaloosa: University of Alabama Press, 1992. Originally written in 1970, this analysis uses English orthography to illustrate Sea Island Creole (SIC) word classes, phrase structures, single and double base transformations, and morphology. The author emphasizes the parallels between SIC and other Creoles. 
Cutter, Martha J. 'Dismantling 'The Master's House:' Critical Literacy in Harriet Jacobs' Incidents in the Life of a Slave Girl."Callaloo, 19.1 (1996), 209-225. This article looks at literacy as a tool by which the slave claims ownership of her own life and becomes empowered to write her story and in doing so, she uses the tool of literacy to debunk notions of inferiority and thereby, dismantle the premises on which her enslavement rests.

Drums and Shadows by the Savannah Unit of the Georgia Writers' Project / WPA University of Georgia Press, 1940. This collection of slave narratives and excerpts were collected by the Savannah field unit of the 1930's Federal Works Project Administration. The stories speak to the history, language, and folklore of the slaves and they do so in the voices of the former slaves themselves.

Gates, Henry Louis Jr. The Signifying Monkey: A Theory of Afro-American Literary Criticism. New York: Oxford University Press, 1988. Looking at African American texts from slave narratives to those of contemporary authors like Alice Walker and Toni Morrison, Gates explores black vernacular traditions and the trope of "signifyin (g)," and their role in African American literature and literary discourse.

Geraty, Virginia Mixson. Porgy: A Gullah Version. Charleston: Wyrick \& Company, 1990. Geraty has taken the play Porgy, by DuBose and Dorothy Heyward and "translated" it into Gullah. Difficult to read by non-Gullah speakers, the book's purpose seems to be an effort to set the record straight linguistically.

Gonzales, Ambrose E. The Black Border, Gullah Sketches of the Carolina Coast. Columbia, S.C., 1922. Gonzales' Black Border series consisted of collected folklore, fables, and anecdotes of the Gullah and he was generally praised for his portrayal of the language.

- - The Captain: Stories of the Black Border. Columbia: The State Co., 1924.

-.- Laguerre, A Gascon of the Black Border. Columbia, 1924.

-.. Two Gullah Tales: The Turkey Hunter and At the Cross Roads Store.

New York: 1926.

-.- With Aesop Along the Black Border. Columbia, 1924.

Goodwine, Marquetta L. and The Clarity Press Gullah Project Ed. The Legacy of Tbo Landing: Gullah Roots of African American Culture. Atlanta: Clarity Press, Inc., 1998. pp. 6-208. A collection of recipes, essays, stories and remembrances, along with some resources and advice for scholars, researchers, and others interested in studying the culture and language.

Goss, Linda and Marian E. Barnes, Ed. Talk That Talk: An Anthology of AfricanAmerican Storytelling. New York: Simon and Schuster/Touchstone, 1989. This anthology contains over 85 stories, encompassing the full range of African 
American rhetorical styles, from animal tales to history, to sermons, to rhymes, and commentaries by contemporary scholars and critics.

Haskell, Ann Sullivan. "The Representation of Gullah-Influenced Dialect in Twentieth Century Prose, 1922-1930." Ph. D. dissertation, University of Pennsylvania, 1964. This dissertation examines the work of seven authors, including Heyward, in terms of the linguistic authenticity of their Gullah representations.

Heyward, DuBose. Porgy. New York: George H. Doran Company, 1925. Novel of post-Reconstruction Charleston and the lives of its Gullah inhabitants.

-. Porgy. ms. 1172.01.04.02(P)01-02 (typed fragments with revisions). South Carolina Historical Society, Charleston.

-. - Porgy. ms. 1172.01.04.02(P)01-04 (typed carbon copy). South Carolina Historical Society, Charleston.

- - Porgy. ms. 1172.01.04.02(P)01-05 (typed ms.). South Carolina Historical Society, Charleston.

Heyward, Jane Screven. "Author's Foreword." Brown Jackets. Columbia, S.C: The State Company, 1923. This small book contains 12 short sketches of the Gullah people Heyward loved and includes her own remembrances, as well as anecdotes gathered from others, many written in Gullah.

- - ms. 1172.03.01.01-07 (Gullah Notebook \#1). South Carolina Historical Society, Charleston.

- - ms. 1172.03.01.01-08 (Gullah Notebook \#2). South Carolina Ilistorical Society, Charleston.

- - ms. 1172.03.01.01-09 (Gullah Notebook \#3). South Carolina Historical Society, Charleston, 1923.

- - ms. 1172.03.01.01-10 (Gullah Notebook \#4). South Carolina Historical Society, Charleston.

.... ms. 1172.03.01.01-11 (Gullah Notebook \#5). South Carolina Historical Society, Charleston.

- - ms. 1172.03.01.01-12 (Gullah Notebook \#6). South Carolina Historical Society, Charleston.

-. - ms. 1172.03.01.01-13 (Gullah Notebook \#7). South Carolina Historical Society, Charleston. 
Holm, John. "The Atlantic Creoles and the Language of the Ex-Slave Recordings." The Emergence of Black English. Ed. Bailey, Guy, Natalie Maynor, Patricia CukorAvila. Amsterdam: Benjamins, 1991, 231-248. Holm examines the language of the ex-slave recordings for its morphosyntactic features and links to the Atlantic Creoles, concluding that American Black English was a semi-creole from its beginning.

Holm, John. Pidgins and Creoles: Volume 1 Theory and Structure. Cambridge: Cambridge University Press, 1988. Traces the history of theories of creole languages and examines the lexical, phonological and syntactic features common to creoles.

Hopkins, Tometro. "Variation in the Use of the Auxiliary Verb da in Contemporary Gullah." The Crucible of Carolina: Essays in the Development of Gullah Language and Culture. Michael Montgomery Ed. Athens: University of Georgia Press, 1994, 60-86. By examining the variations of the Gullah verb $d a$, Hopkins argues that the creole continuum model may, in fact, be unilinear in nature.

Hutchisson, James M. DuBose Heyward: A Charleston Gentleman and the World of Porgy and Bess. Jackson: University Press of Mississippi, 2000. This biography uses primary documents from Heyward's estate as source material and examines Heyward's work in the context of his personal history and his influences.

Johnson, Guy B. "The Gullah Dialect Revisited: 30 Years Later." Given as a paper at the Annual meeting of the American Anthropological Association, Washington, D.C.s 1967. Published as "The Gullah Dialect Revisited: a Note on Linguistic Acculturation." Journal of Black Studies. vol. 10, no. 4, June 1980, 417-424. Johnson compares the speech he observed in St. Helena in 1930 and in 1965 and concludes that acculturation essentially eliminated African speech patterns in the 35 year interim. He believes that Gullah is substandard English and can be attributed to speech problems in the underprivileged Negroes.

Jones, Charles C. Jr. Negro Myths From the Georgia Coast. Detroit: Singing Tree Press, 1969 (1888). Jones presents what he describes as coastal versions of the African animal tales made famous by Joel Chandler Harris, along with a number of anecdotal plantation tales. Jones' use of Gullah dialogue is generally praised for its accuracy.

Jones-Jackson, Patricia. "On Decreolization and Language Death in Gullah." Language in Society, 13:3 (1984 Sept.), 351-362. Jones-Jackson makes the case that Gullah is showing signs of both elaboration and attrition, clear markers that it is decreolizing. 
Jones-Jackson, Patricia. "The Audience in Gullah and Igbo: A Comparison of Oral Traditions," College Language Association Journal, 27:2 (1983 Dec.), 197-209. Jones-Jackson compares the role of the audience in the storytelling traditions in both Gullah and Igbo (an African language) and finds many similarities, from the call and response technique to audience support and affirmation of the storyteller.

Joyner, Charles W. Down by the riverside: a South Carolina slave community. Urbana: University of llinois Press, 1984. Through extensive historical research, Joyner provides a detailed picture of the personal, social, and economic reality of slavery in one community.

Lavely, Marcia Marvin. A Study of American Literature which Incorporates the use of the Gullah Dialect. Ann Arbor: UMI, 1992. pp.1-483. An extremely thorough work, Lavely surveys fiction, poetry, and spirituals in her comprehensive look at literature using Gullah.

Mellon, James Ed. Bullwhip Days. New York: Weidenfeld \& Nicolson, 1988. This is a collection of 29 slave narratives that were recorded as part of the 1930 's Federal Works Project Administration. The narratives, along with excerpts from other narratives on specific topics, provide an inside look at the slaves' lives and the day-to-day reality of slavery.

Mille, Katherine Wyly, and Michael Montgomery. "Introduction." 2001. Africanisms in the Gullah Dialect by Lorenzo Dow Turner. Colombia: University of South Carolina Press, 2001 (1949). This article provides biographical information on Turner and places his work in its socio-historical context. It reexamines the text from a contemporary perspective and calls for educators to recognize the language and its contribution to American linguistic history.

Mitchell, W. J. T. "Narrative, Memory, and Slavery," pp. 199-222. Ezell, Margaret J. M. (ed. and introd.); and O'Keeffe, Katherine O'Brien (ed. and introd.). Cultural Artifacts and the Production of Meaning: The Page, the Image, and the Body. Ann Arbor, MI: U of Michigan P, 1994. $252 \mathrm{pp}$. The author looks at the oral histories of the slave narratives in terms of the literary realities of reconstructed memory, personal motivation and narrative techniques.

Montgomery, Michael. "Africanisms in the American South." Africanisms in AfroAmerican Language Varieties. Salikoko Mufwene Ed. Athens: University of Georgia Press, 1993. This paper examines various viewpoints as to the African influence in the language of the American South, from a historical perspective.

Morrison, Toni. Playing in the Dark: Whiteness and the Literary Imagination. Cambridge: Harvard University Press, 1992. Morrison looks at the construction of "literary whiteness" and the awareness of race and their effect on the literary imagination. 
Mufwene, Salikoko S. "Is Gullah Decreolizing? A Comparison of a Speech Sample of the 1930 s with a Sample of the 1980s." The Emergence of Black English: Text and Commentary. Ed. Bailey, Guy and Natalie Maynor, Patricia Cukor-Avila. Amsterdam: Benjamins, 1991, 213-30. Mufwene takes issue with claims that Gullah is decreolizing, based on examinations of late- $18^{\text {th }}$ and early- $19^{\text {th }}$ century literary texts. He conducts his own study, using an actual speech sample, and concludes that the signs of decreolization are not as apparent as has been claimed.

Mufwene, Salikoko S. "Some Reasons Why Gullah Is Not Dying Yet." English WorldWide: A Journal of Varieties of English, 12:2 (1991), pp. 215-43. Mufwene says that the funcral plans for the Gullah language should not be made just yet. He points to indications that, like Black English, Gullah is gaining some in status or at least losing some of the negative status from its early association with a lack of education or literacy. He examines the "code" aspect, or that of Gullah being a language that is not available to outsiders and whose use carries a cachet as it identifies the user as part of the inner circle and thus, exclusive.

Mufwene, Salikoko S. "The Ecology of Gullah's Survival." American Speech: A Quarterly of Linguistic Usage, 72:1 (1997 Spring), pp. 69-83. Mufwene uses the term "language ecology" to refer to social and psychological factors that bear on the structure and fate of a language variety. He discusses factors such as group identity, solidarity, loyalty, variation within the variety, residential patterns, and the ability to code-switch. He argues that the patterns of social interaction combined with the idea of linguistic identity and cultural loyalty, may contribute to Gullah's survival. He cites economics as the greatest threat, with the subsequent demographic erosion that reduces the number of speakers.

Napier, Winston Ed. African American Literary Theory. NY: New York University Press, 2000. This comprehensive reader contains over 50 essays of Black criticism and literary theory from the 1920 's to the present.

Seabrook, Charles. "Gullah-Geechee Heritage in Peril, Group Says." The Atlanta Constitution, May 25, 2004, 1A. The article reports on the move by the National Trust for Historic Preservation to place the loosely-defined "Gullah-Geechee Coasts" on the Trust's 2004 list of the 11 Most Endangered Historic Places.

Sledge, Mailande Cheney. "The Verisimilitude of the Gullah Dialect in Francis Griswold's A Sea Island Lady." Methods in Dialectology. Ed. Thomas, Alan R. (ed. \& pref.) Ball, Martin J. (introd.). Clevedon: Multiling. Matters, 1988, 625636. Sledge examines Griswold's 1939 novel and its representation of Gullah dialogue by looking at phonological and grammatical features, and Griswold's methods of respelling using orthography. 
Smith, Bruce. "Project Works to Protect Property Rights of Blacks Along Coast." The Miami Herald, Sept. 7, 2003,22A. The article reports on the first year success of a legal aid project implemented to address the issue of unclear title on land called "heir's property," or land granted to, or bought by, former slaves after emancipation and passed down to heirs without a will.

Smitherman, Geneva. Talkin and Testifyin: The Language of Black America. Boston: Houghton Mifflin Company, 1977. The author examines the elements of Black English in the context of its history and socio-cultural development. She concludes with some suggestions for educational policy and practice.

Straight, Susan. IBeen in Sorrow's Kitchen and Licked Out all the Pots. New York: Hyperion, 1992. This work of fiction tells the story of a backcountry Gullah girl who comes to the mainland in search of work and a better life. She gets pregnant and has twin sons, whom she raises with the help of a new "family" she creates. The sons grow up and go on to successful careers in professional sports while their mother finds her own way to happiness. The novel's treatment of the Gullah language and culture is well done.

Turner, Lorenzo Dow. Africanisms in the Gullah Dialect. Chicago: University of Chicago Press, 1949. Turner's painstaking detail and knowledge of multiple African languages provides convincing evidence of Gullah's African roots. The text includes: sections on names and naming; on African words that have survived intact and others that clearly show their African roots; and explanations and examples of syntactic, morphologic and other linguistic categories and usage in Gullah with comparisons to a number of specific African languages. He uses the International Phonetic Alphabet with English translations for all examples.

Twining, Mary A. Ed. and Keith E. Baird. Sea Island roots : African presence in the Carolinas and Georgia. Foreword by John Henrik Clarke. Trenton: Africa World Press, 1991. One of the most interesting sections of this work is the discussion about the fluidity of a creole language, particularly in a non-literate population. The authors emphasize that the creole is spoken at varying levels of complexity depending on the audience and their ethnic, geographic, or cultural origin. In discussing the work of Johnson who attempted to debunk Turner's work, they speculate that Johnson, who was white, never heard the deeper creole or basilect that Turner, who was black, heard.

Wall, Cheryl A. Women of the Harlem Renaissance. Bloomington: Indiana University Press, 1995. This work examines Nella Larson, Jessie Redmon Fauset, Zora Neale Hurston and other women of the Harlem Renaissance for their literary contributions to the H.R. aesthetic.

Warren, Kenneth W. Black and White Strangers: Race and American Literary Realism. Chicago: The University of Chicago Press, 1993. Warren examines race as an 
essential component of the literary genre of American Literary Realism and one that had a profound effect on the post-Reconstruction politics and society. 